\title{
MIDDLE AND LATE COPPER AGE SETTLEMENTS FROM THE BRÎNZENI MICROZONE ON THE PRUT RIVER: OLDER RESEARCH IN A MODERN BACKGROUND
}

\begin{abstract}
Țerna S. and Heghea S. 2017. Middle and Late Copper Age settlements from the Brînzeni microzone on the Prut river: older research in a modern background. Sprawozdania Archeologiczne 69, 297-325.

The article presents an overview of the fieldwork from $\mathrm{XX}^{\text {th }}$ century performed mainly by the Moldavian archaeologist V. Marchevici in the outskirts of the Brînzeni village (Edineț district, Republic of Moldova). The investigated sites refer to the middle and late stages of the Cucuteni-Tripolye culture's evolution. Features unearthed on these settlements as well as the archaeological materials offer important data both for the research of formation of the specific Cucuteni-Tripolye large settlements and for the analysis of the subsequent disintegration and fragmentation of culture in the Final Copper Age.
\end{abstract}

Keywords: Cucuteni-Tripolye culture, Republic of Moldova, large sites, settlement layout, Brînzeni stage, burnt houses

Received: 22.04.2017; Revised: 10.05.2017; Accepted: 03.07.2017

\section{INTRODUCTION}

Within the vast area occupied by the Copper Age Cucuteni-Tripolye culture in the early $5^{\text {th }}$ - end of $4^{\text {th }}$ millennia BC, the middle Prut region is well-known for the high number of important settlements from the late and latest stages of the Cucuteni-Tripolye culture's

\footnotetext{
* "High Anthropological School” University, Iorga 5 str., Chişinău, MD-2029; Moldova and National Museum of History of Moldova, 31 August 1989, 121A str., Chişinău, MD-2012 Moldova; ternastas@mail.ru

** Center for Archaeology, Institute of Cultural Heritage, Academy of Sciences of the Republic of Moldova, Ştefan cel Mare 1 bld., Chişinău, MD-2001 Moldova; sheghea@gmail.com
} 
evolution, some of which are eponymous for distinct Cucuteni B - Tripolye B2/C1 and post-Cucuteni - Tripolye C2 local groups (Dergachev 1980; Markevich 1981; Chernysh 1982; Boghian 2001; Dumitroaia 2000; Manzura 1994). The archaeological investigation of prehistoric sites on the Prut river started in the period before the Second World War (Moroşan 1929; Ambrojevici 1932; Dumitrescu 1945). From then onward, especially beginning with the 1960'-1970's, the left bank of the river has been subject to intensive research initiated and performed mainly by the Moldavian archaeologists N. Chetraru and V. Marchevici. As a consequence, V. Marchevici published a first - and to date only - extensive corpus of Cucuteni-Tripolye sites in Moldova (Markevich 1973), followed by a monograph (Markevich 1981) dealing with the late-Tripolyan settlements from the northern part of the country, which was broadly based on his investigations of sites from the Prut region. On the right bank, research was not so intense; still, several important sites have been investigated (Dinu 1977; Niţu and Şadurschi 1994; Burtănescu and Şadurschi 2013).

After a 20-year break, the intensity of research of middle and late Cucuteni-Tripolye sites in the Prut area started to grow in recent years. Archaeological excavations in Ripiceni - Holm (Melniciuc and Boghian 2010) and Trinca (Levițki et al. 2013; Levițki et al. 2016) followed by geophysical prospection in Cobani (Rassmann et al. 2016), Stolniceni (Țerna et al. 2016) and Ripiceni (Boghian et al. 2016) revealed new data on the material culture, settlement layout, relative and absolute chronology of Copper Age settlements. Combined with the older results of aerial photography (Bicbaev 2007) as well as the identification of new settlements using satellite imagery (Vornicu-Țerna and Țerna 2016), recent research may offer important information on the formation of large Cucuteni-Tripolye sites - a problem highly disputed recently in light of a new stage of investigation of giant settlements in Ukraine (Chapman et al. 2014; Rassmann et al. 2014; Müller et al. 2016). A good example for the potential of research in the Prut area is the ongoing work at Stolniceni I site which provided extremely valuable information on settlement layout (TTerna et al. 2016a) and various archaeological features such as pottery kilns, palisade, ditches and access paths (Țerna et al. 2016b; Țerna et al. 2017) on a complex Tripolye settlement located far to the west from the Bug-Dnieper region.

In this context, of special importance is the re-evaluation of the previous work conducted mainly by V. Marchevici. Unfortunately, most of the results of his large-scale excavations remain unpublished. Thus, systematization and a modern assessment of the scientific legacy of this great Moldavian scientist will be a task for the future.

Within this objective, we started to prepare the materials from the important Tripolye B2 site of Brînzeni VIII (S. Țerna) and Tripolye C2 settlement of Brînzeni III (S. Heghea) for publication as monographs. One first step in the evaluation of the data shall be a general presentation of the Brînzeni microzone and its importance for Cucuteni-Tripolye studies. This article is an attempt to highlight the Copper Age settlements from the Brînzeni microzone (Fig. 1A) investigated by V. Marchevici and their position within the Cucuteni-Tripolye cultural milieu. 


\section{NATURAL BACKGROUND}

The sites which we will present in this paper lie on the outskirts of Brînzeni village (Edineț district, Republic of Moldova). The Prut area of Northern Moldavian region is characterized by a non-homogenous relief (Băcăuanu 1968) which includes canyons built by erosion, tortuous river banks with steep slopes intersected by gentle large valleys and low flat promontories which still partly preserve the ancient woodlands (Markevich 1981, 10-12). Such a non-uniform configuration of relief is well illustrated by the Brînzeni microzone which offered various settling conditions for different settlement types (Fig. 1B-C).

In the following we will briefly present the settlements from the Brînzeni microzone, namely their location, stratigraphy, history of research, archaeological features, finds, layout, chronology and perspectives for further research.

\section{BRÎNZENI VIII - "SÂECI"}

\section{Site location, stratigraphy, description and history of research}

The settlement lies on a high promontory built by the confluence of Racovăț and Draghişte rivers (Fig. 1B-C; 2). The promontory has a rounded shape with a rectangular brow in the south-eastern part. The absolute height of the promontory is about $110 \mathrm{~m}$ above sea level while the relative height above Racovăț and Draghişte rivers represents circa 10-12 m.

The area of the settlement is almost 30 ha. Archaeological stratigraphy includes Paleolithic finds, a consistent Copper Age site, Late Copper Age finds and a Sarmatian necropolis from the first centuries AD.

The settlement was discovered in 1966 by N. Chetraru (Markevich 1973, 60-61). In the late 1970's, K. Shishkin made aerial photos of the site and identified its internal structure (see below). In 1979-1980, V. Marchevici opened 5 trenches in different parts of the settlement. Materials from these investigations remain almost unpublished, with the exception of anthropomorphic figurines (Sorochin 2001) and several finds included into various catalogues (Markevich 1985; Stratulat 2009). The features unearthed are also unpublished, except for a brief note in a conference proceedings (Markevich 1990). The main information is contained in the field reports deposited in the Archive of the National Museum of History of Moldova (Markevich 1980; 1981a).

\section{Archaeological features}

Eight dwellings and several pits were excavated. Trenches 1-4 were located in different parts of the settlement and were opened in 1979. Trench no. 5, the largest one, was opened in 1980 (Fig. 3). 
We should emphasize that in the following description the dwellings are numbered according to their preservation; so, distinct numbers have been assigned only to the burnt daub agglomerations which surely belong to distinct house remains. It should be noted here, however, that in several trenches other scarce construction remains have been also encountered, but their weak state of preservation does not allow us to draw conclusions about the initial outline and function of these features.

Dwelling no. 1 was investigated in the first trench. It was partly destroyed in the postTripolye time; the preserved dimensions are $4.5 \mathrm{~m}$ on the NE-SW axis and $4 \mathrm{~m}$ on the NW-SE axis. Judging by the imprints of beams on the ground floor ceiling, the two-storey dwelling was oriented on the NE-SW axis; thus, its width can be reconstructed and represents $4 \mathrm{~m}$. The beams were $15-25 \mathrm{~cm}$ wide while the clay layer of the platform was about $5 \mathrm{~cm}$ thick. Fragments from several vessels together with stone and bone artefacts were located on the natural earthen floor of the ground level.

Dwelling no. 2 was unearthed in the second trench and had the dimensions of $9.3 \times 4.5 \mathrm{~m}$, with the orientation on NE-SW axis. It was quite well preserved and allowed the excavators to record its two-storey construction. The ceiling of the ground floor (= floor of the upper level) represented a typical clay platform mounted on half-beams over $4.5 \mathrm{~m}$ long. The beams were 10-22 cm wide and the clay coating was about $3 \mathrm{~cm}$ thick. Remains from a clay installation of an unknown type were found on the upper floor, on an area of circa $100 \times 120 \mathrm{~cm}$. The ground floor contained an oven with pottery fragments inserted into the clay bed in order to increase its thermal capacity. The inventory of the house consisted of fragments from pottery vessels on both floors.

It should be highlighted here that in both trenches no. 1 and 2 some elongated shallow dugout features were excavated. In the opinion of V. Marchevici, these could refer to a ditch marking the limits of an early phase of settlement's occupation (Markevich 1980, 40-42).

Dwelling no. 3 was investigated in the third trench but it was very badly preserved. The reconstructed dimensions are $8.5 \times 4.5 \mathrm{~m}$ oriented on the NNE-SSW axis. Construction of the dwelling is similar to the already described ones - a two-storey structure with a platform built of half-beams covered with a layer of clay. To the west of the dwelling a shallow structure (cavity) was investigated, containing pottery fragments, animal bones and two grinding stones. In the eastern part of the trench another agglomeration of burnt clay was found - the possible remains of another destroyed dwelling.

Trench no. 4 contained burnt daub from a partially destroyed dwelling (no. 4) as well as some other construction remains.

Particularly interesting is the find of a painted amphora covered with a lid in trench 1. Morphologically and stylistically they belong to a later Cucuteni-Tripolye stage (Tripolye C2) and are not connected with the inventory of burnt dwellings. Therefore, the presence of a later occupation (or even necropolis) on the territory of the settlement is not to be excluded. 

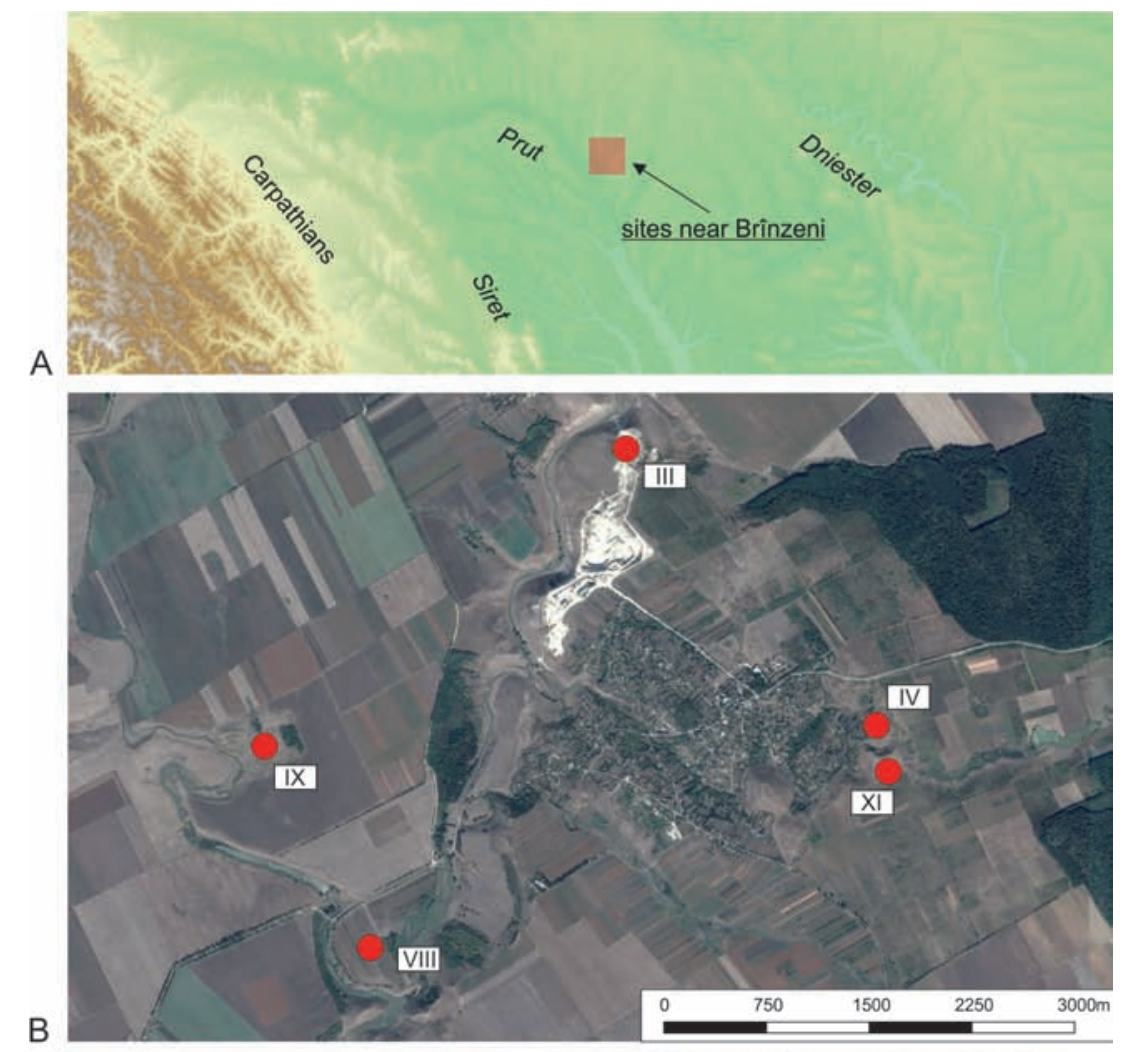

B

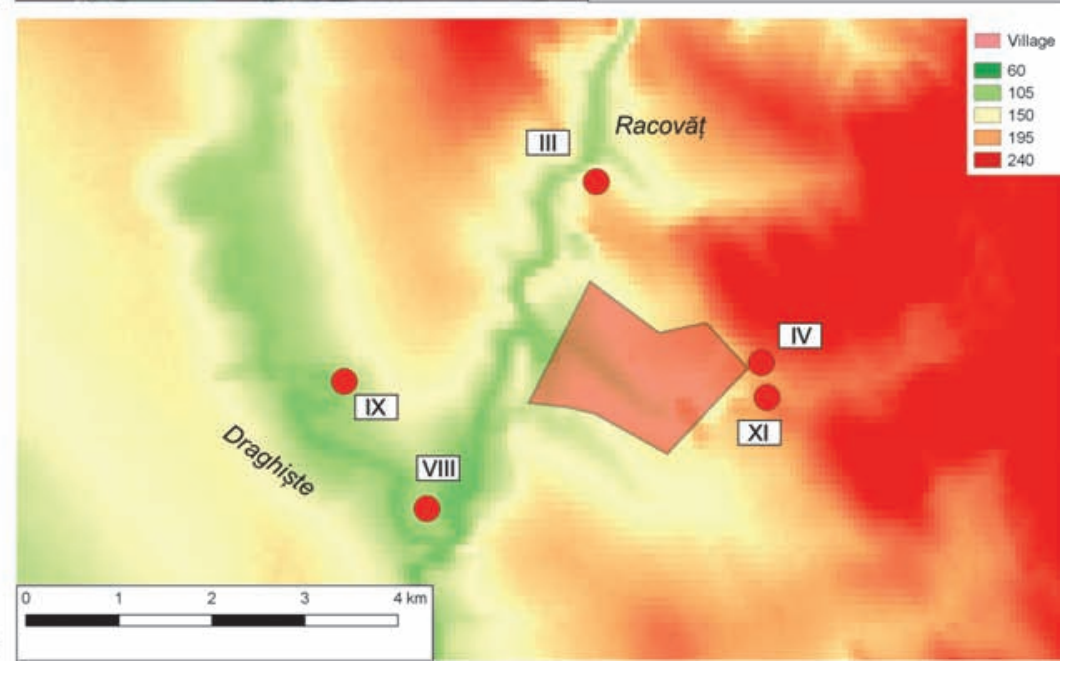

Fig. 1. A - location of Brînzeni microzone on the physical map of the Carpathians - Dniester region, $\mathrm{B}$ - location of sites on the Google Earth satellite picture, C - location of sites on the physical map of the Brînzeni microzone. Source for physical maps - SRTM 30 

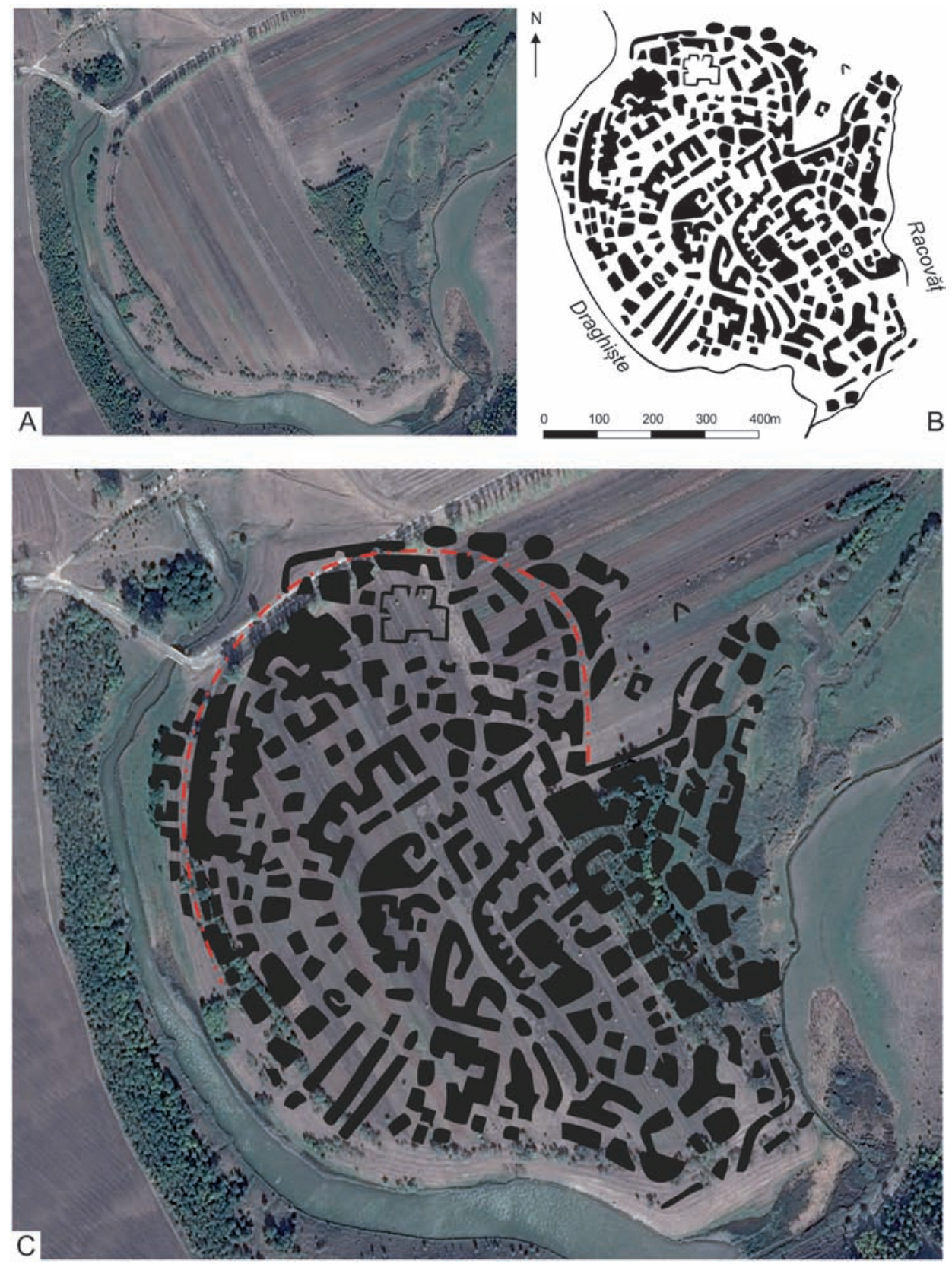

Fig. 2. Brînzeni VIII. A - Google Earth satellite picture of the site (15.09.2015), B - Shishkin's interpretation of the aerial picture of the site, made in the late 1970's (after Sorochin 1993), C - overlap of both images with the red line indicating the location of the possible ditch, visible both on modern satellite picture and Shishkin's layout 


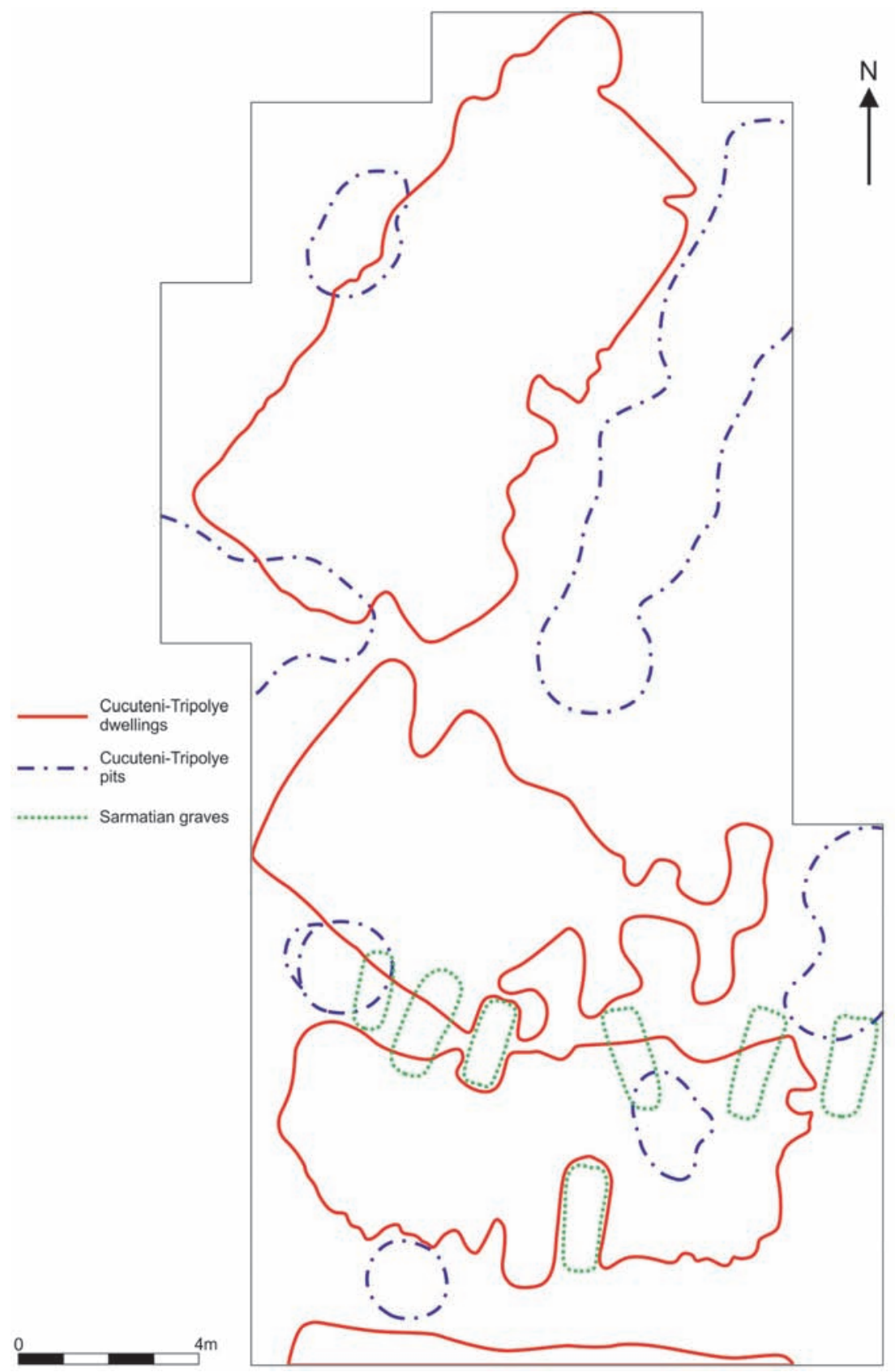

Fig. 3. Brînzeni VIII. Plan of trench $5 / 1980$ with the outlines of archaeological features. A - Cucuteni-Tripolye dwellings, B - Cucuteni-Tripolye pits, C - Sarmatian graves. Redrawn from the field report of V. Marchevici (Markevich 1981a) 

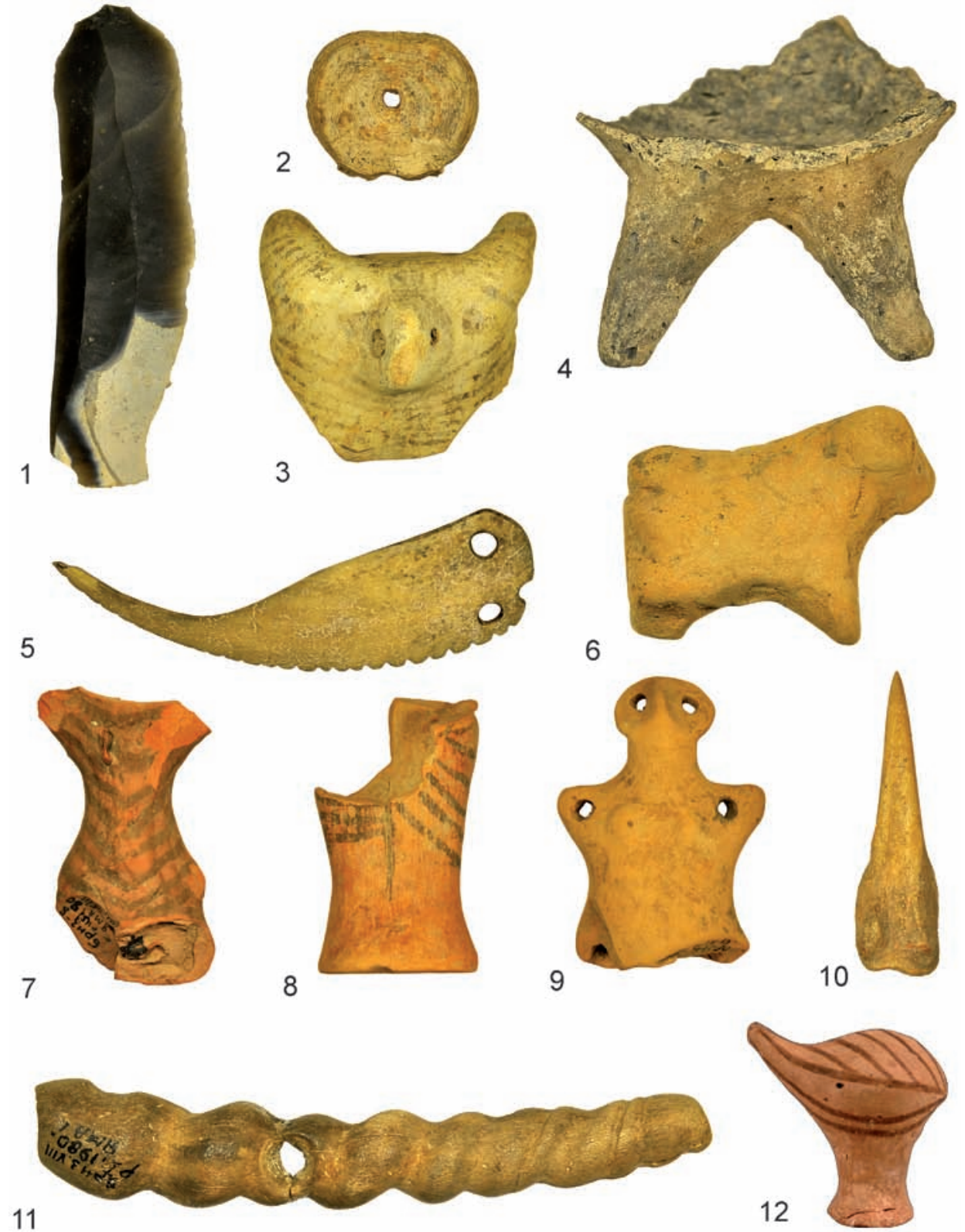

Fig. 10. Brînzeni VIII. Small finds. 1 - flint; 2 - fish vertebra; 3-4, 6-9, 12 - clay; 5, 10: bone; 11 - antler 


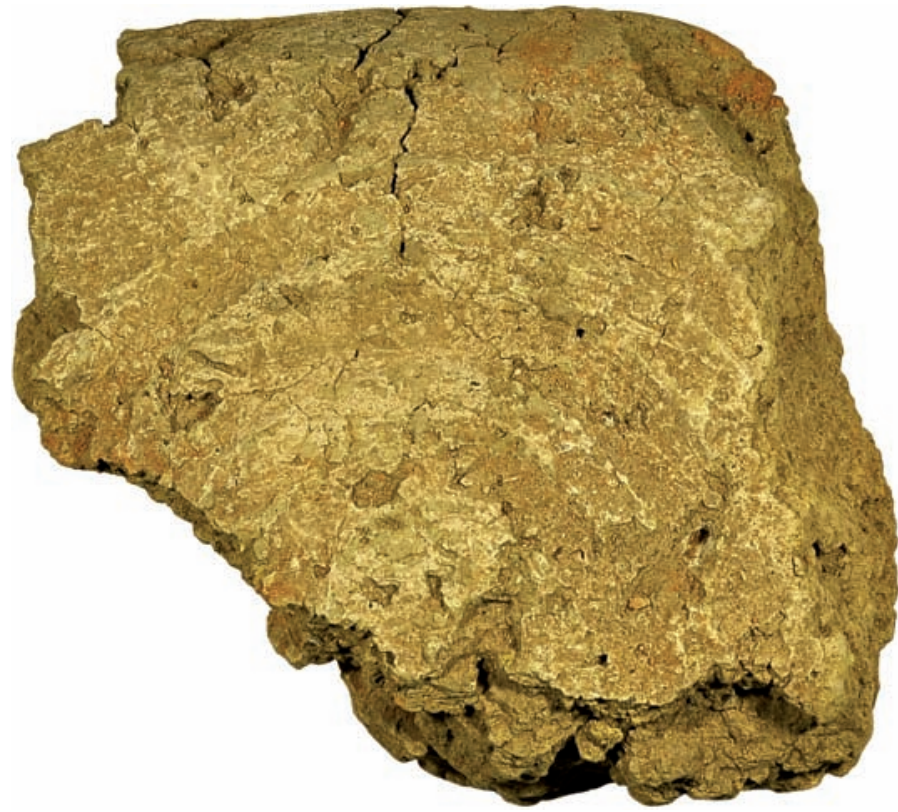

Fig. 11. Brînzeni VIII. Fragment of a clay installation with traces of spiral channelled ornamentation

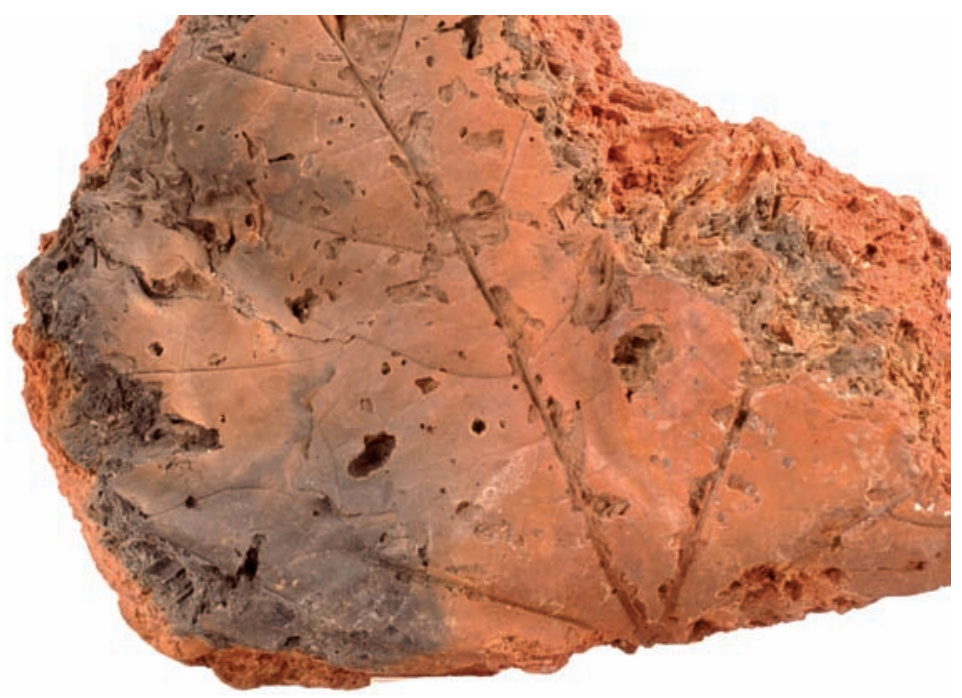

Fig. 12. Brînzeni VIII. Daub fragment with imprint of a grape leaf 


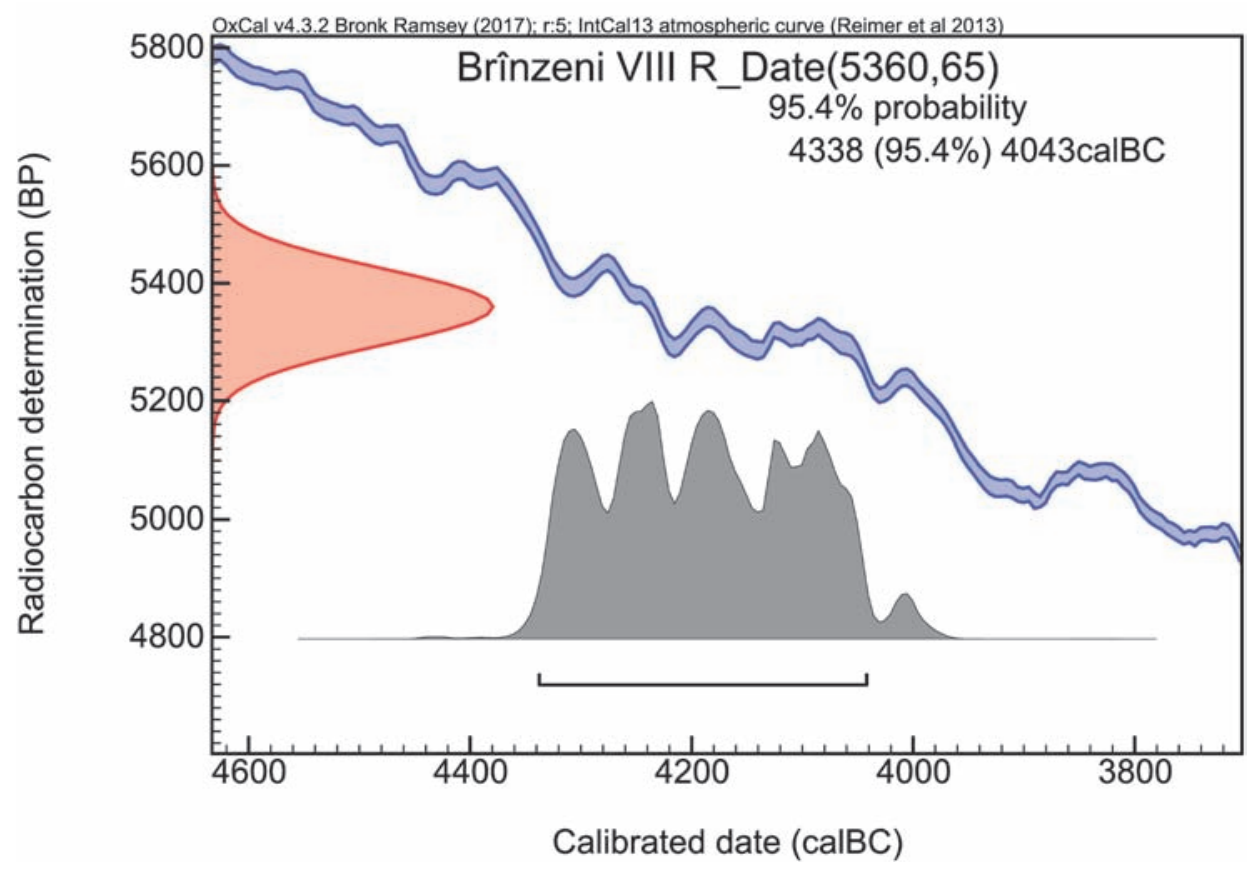

Fig. 13. Brînzeni VIII. OxCal calibration of the radiocarbon date (Bln-2429, BP $5360 \pm 65$, published in Wechler 1994) 

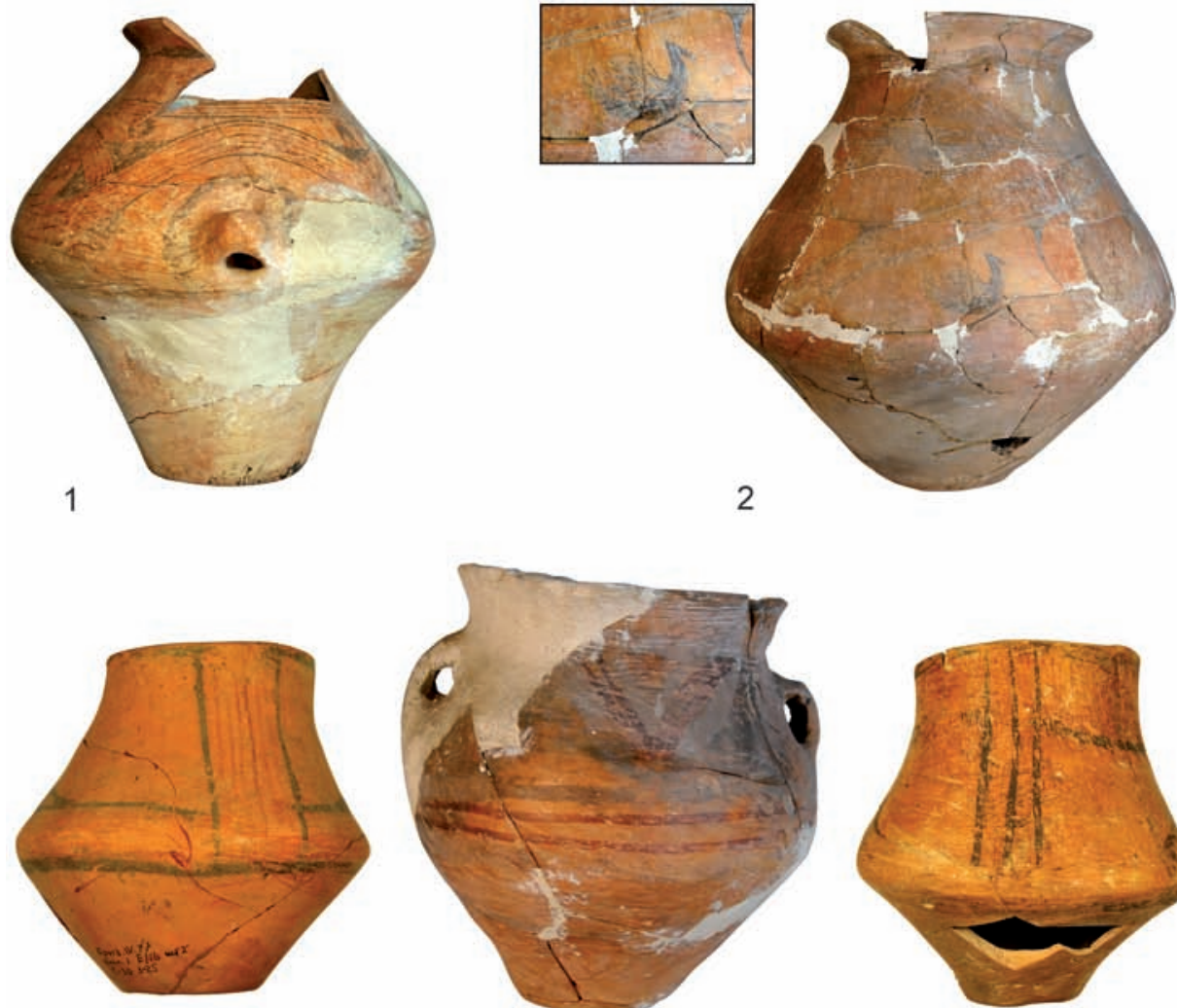

3
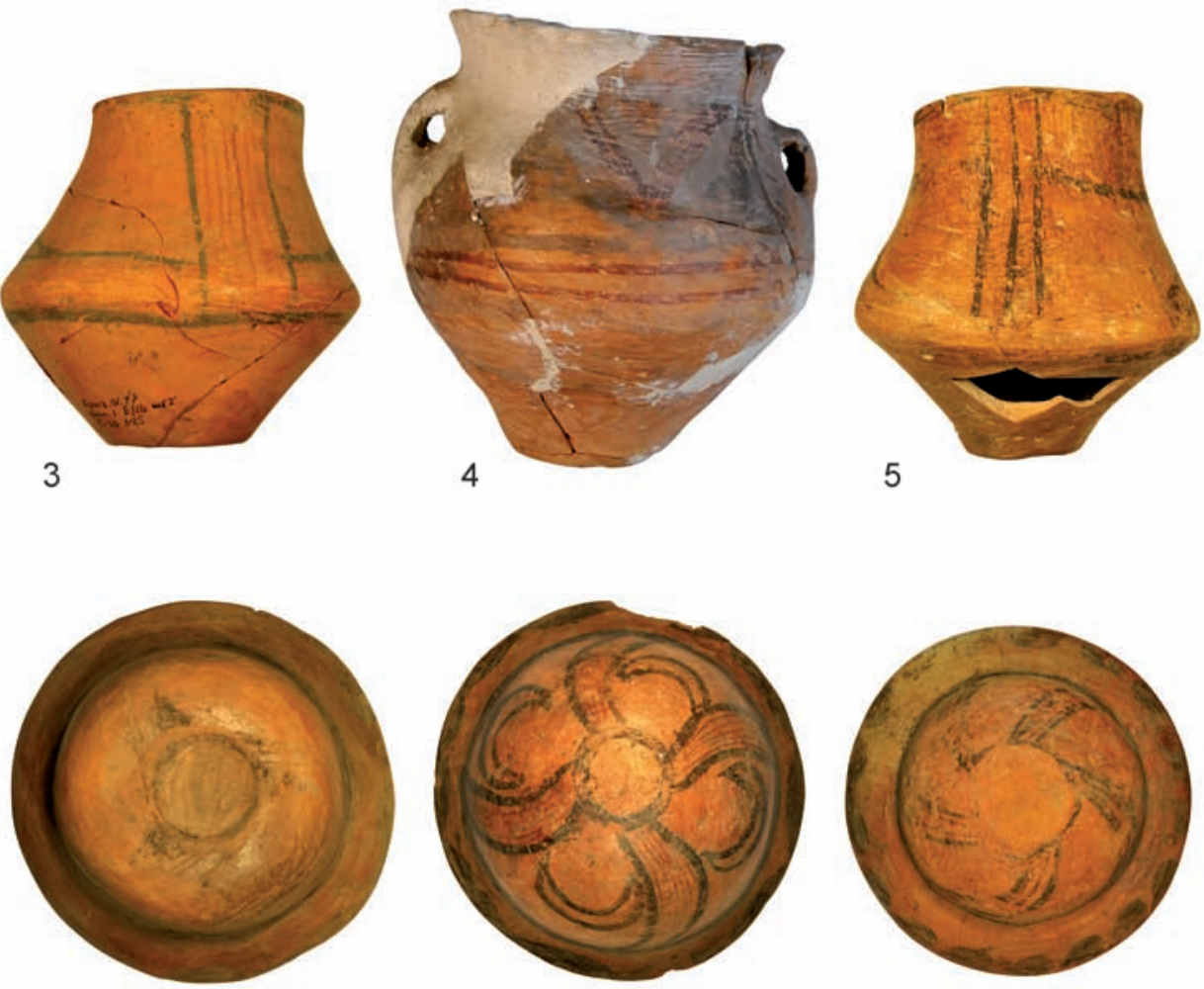

6
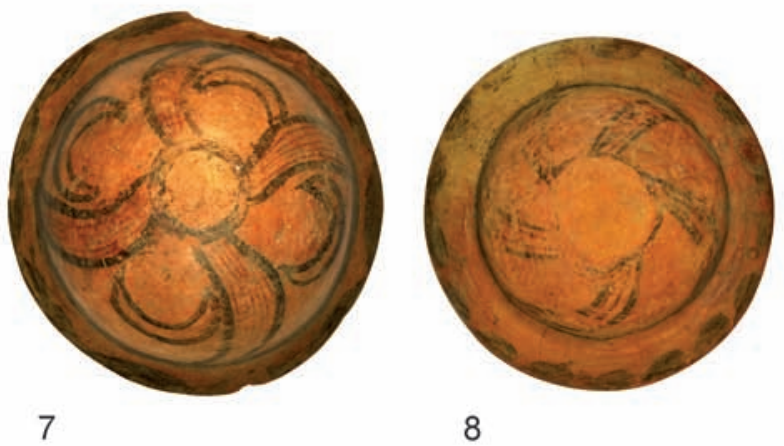

Fig. 14. Brînzeni IV. 1-9 - fine pottery of the Cucuteni B - Tripolye C1 layer 

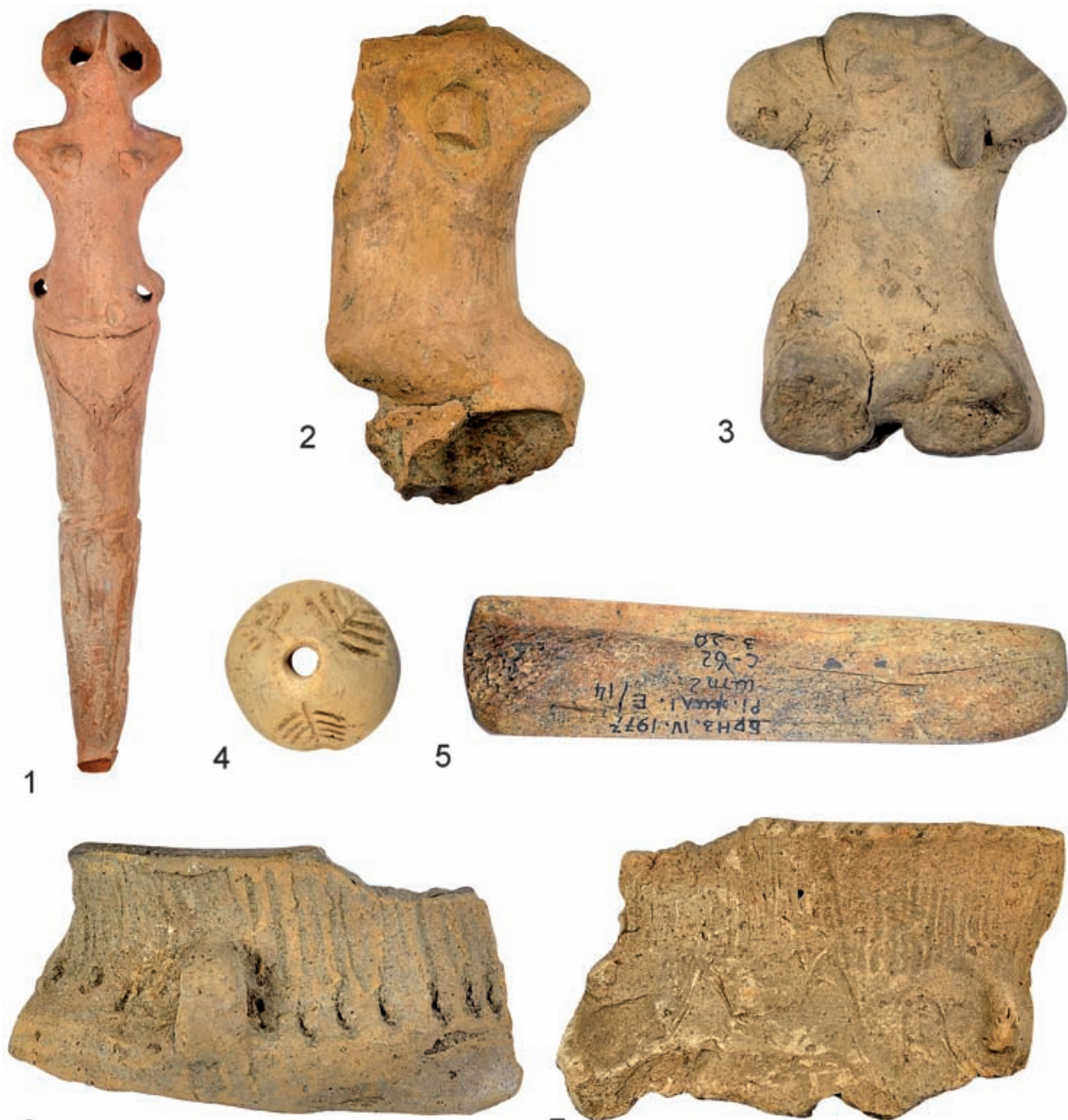

6

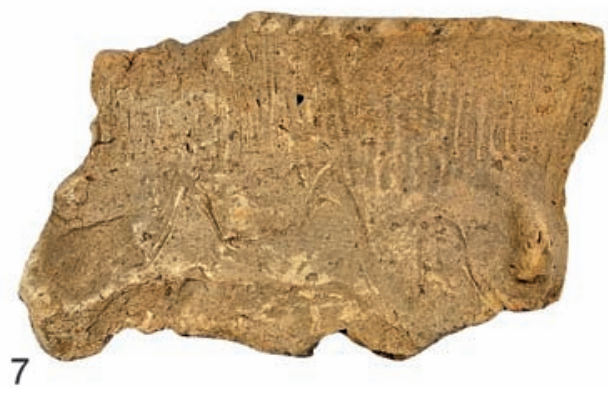

Fig. 15. Brînzeni IV. Cucuteni B - Tripolye C1 layer. 1-5 - small finds (1-4 - clay, 5 - bone); 6-7-coarse ware 

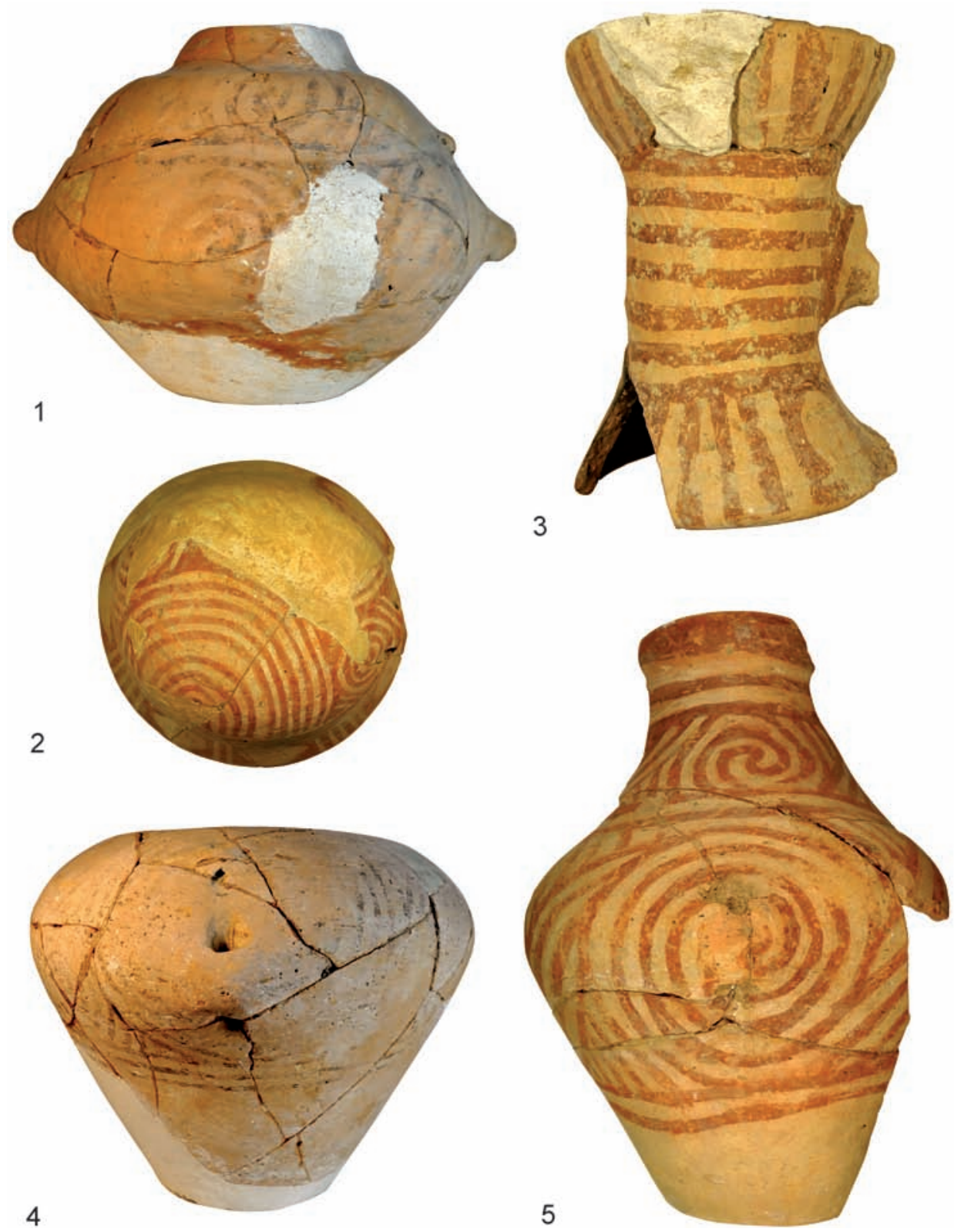

Fig. 16. Brînzeni IV. 1-5 - fine pottery from the Cucuteni A/A-B - Tripolye B1 pit 

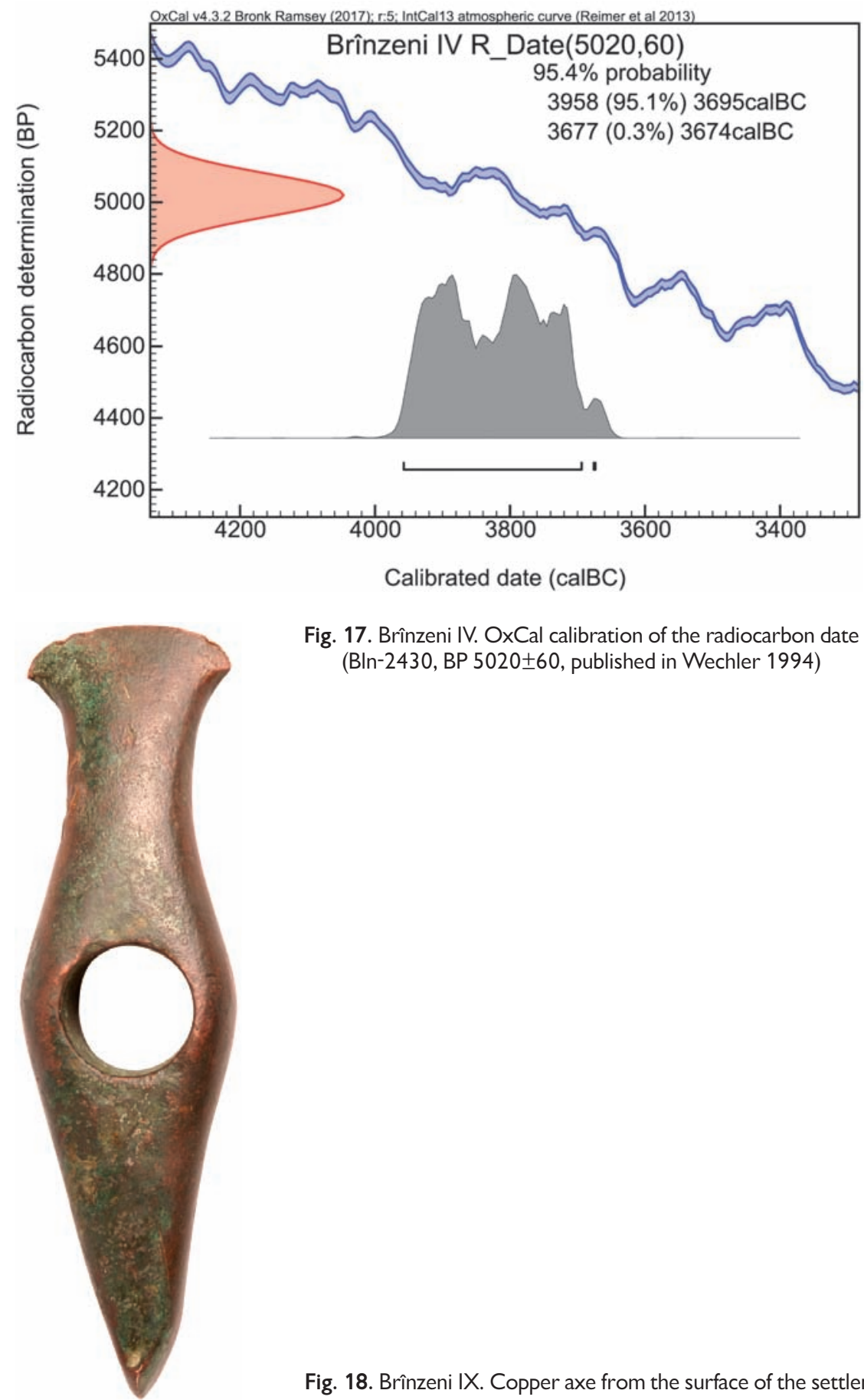

Fig. 17. Brînzeni IV. OxCal calibration of the radiocarbon date (Bln-2430, BP 5020 \pm 60 , published in Wechler 1994)

Fig. 18. Brînzeni IX. Copper axe from the surface of the settlement 

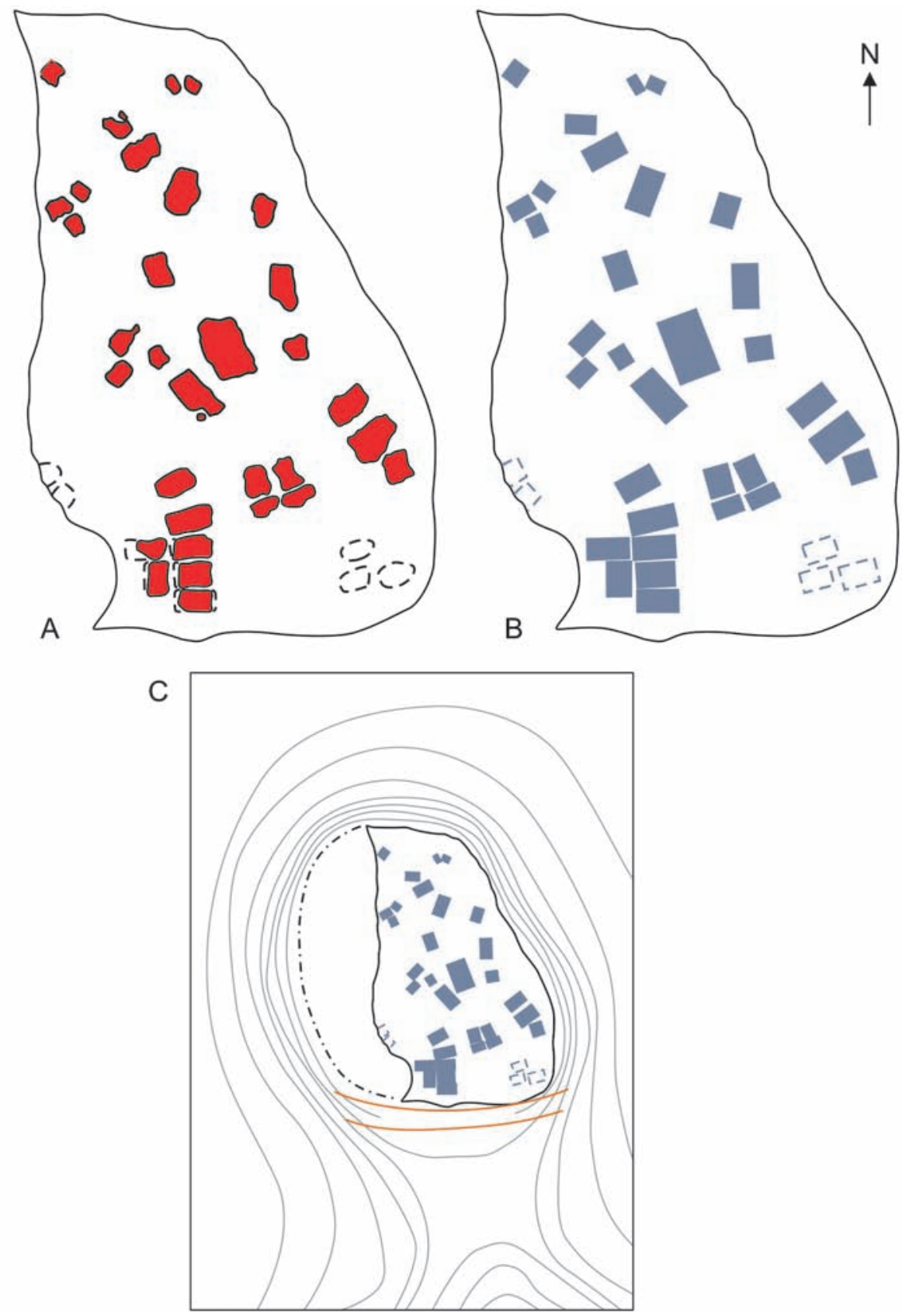

Fig. 19. Brînzeni III. A - plan of the excavated houses; B - idealized settlement layout according to the excavation plan; $\mathrm{C}$ - schematic plan of the promontory with the excavated part of the site and layout of burnt houses 

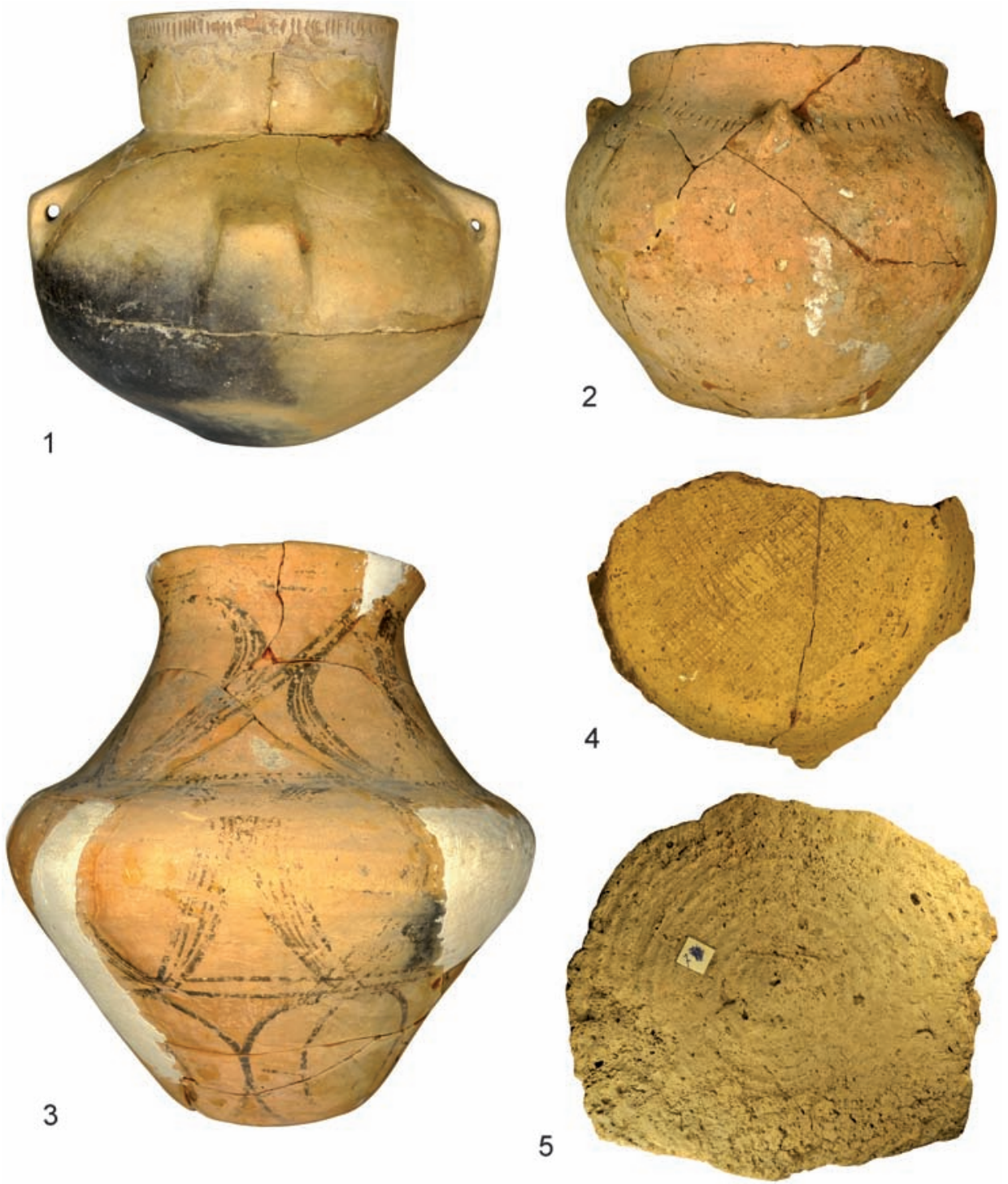

Fig. 21. Brînzeni III. Fine pottery. 1 - Funnel beaker import; 2-5 - Tripolye C2 ware 

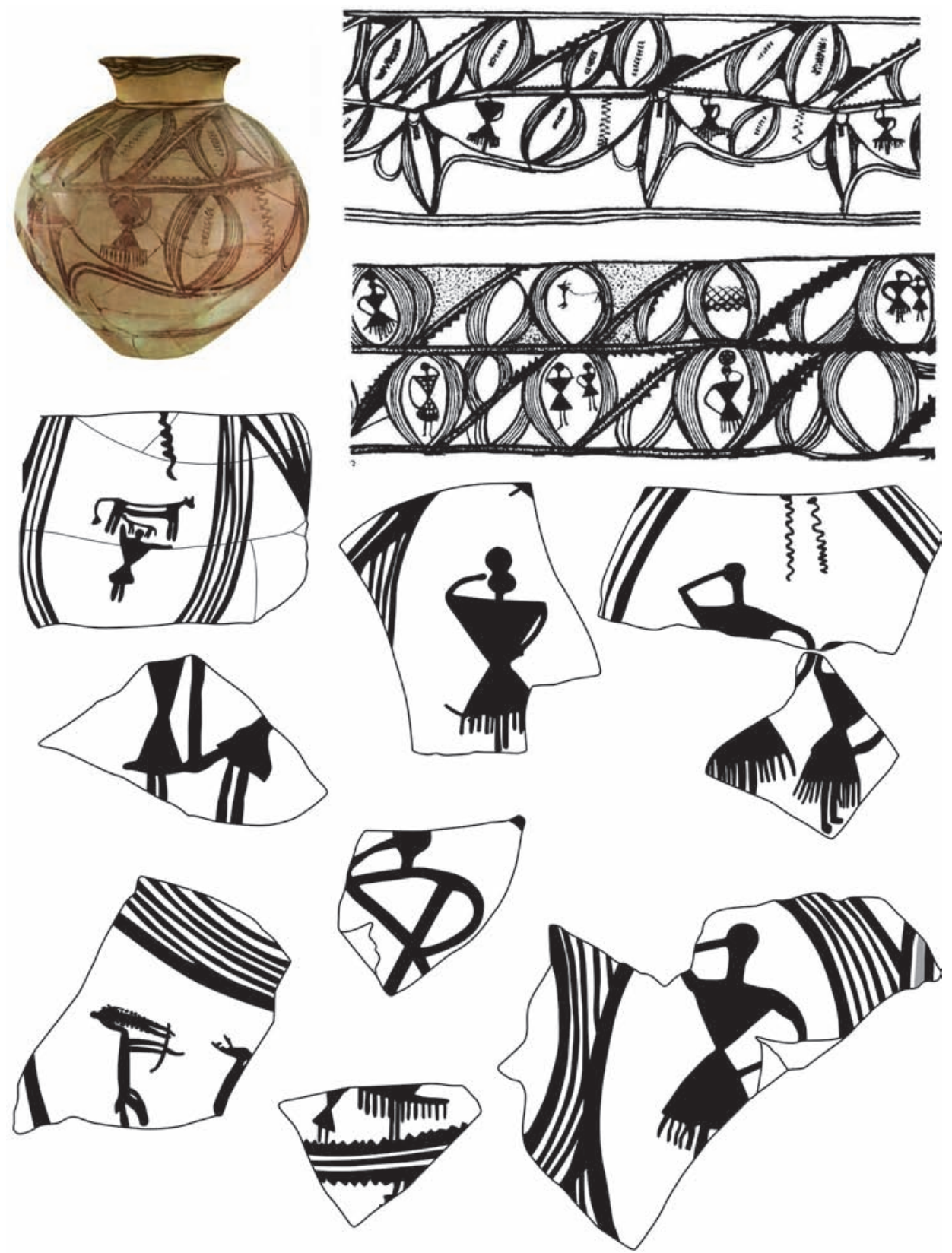

Fig. 22. Brînzeni III. Painted anthropomorphic representations on the fine ware 

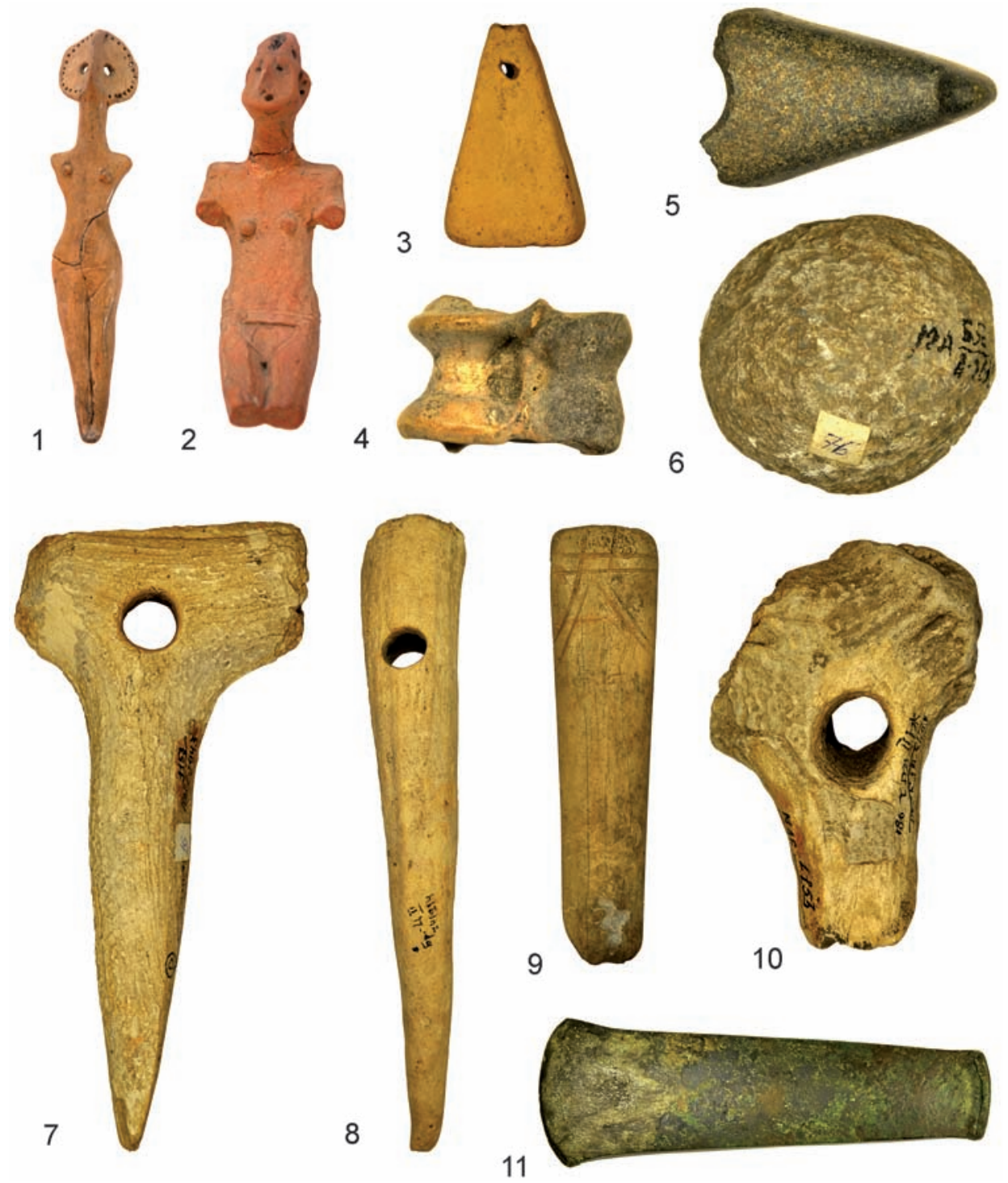

Fig. 23. Brînzeni III. Small finds. 1-3 - clay; 4, 7-10 - bone and antler; 5-6: stone; 11 - copper 

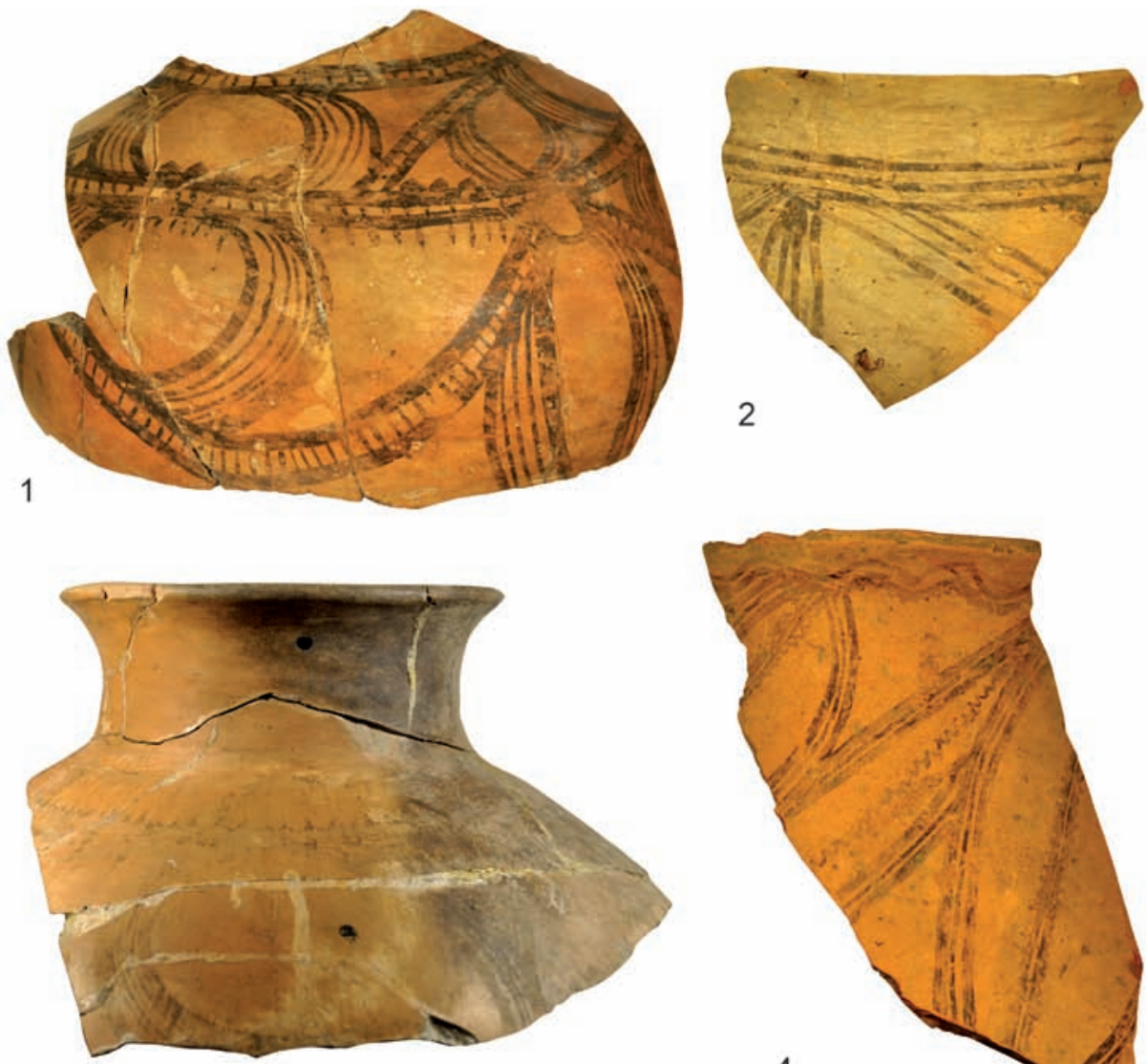

3
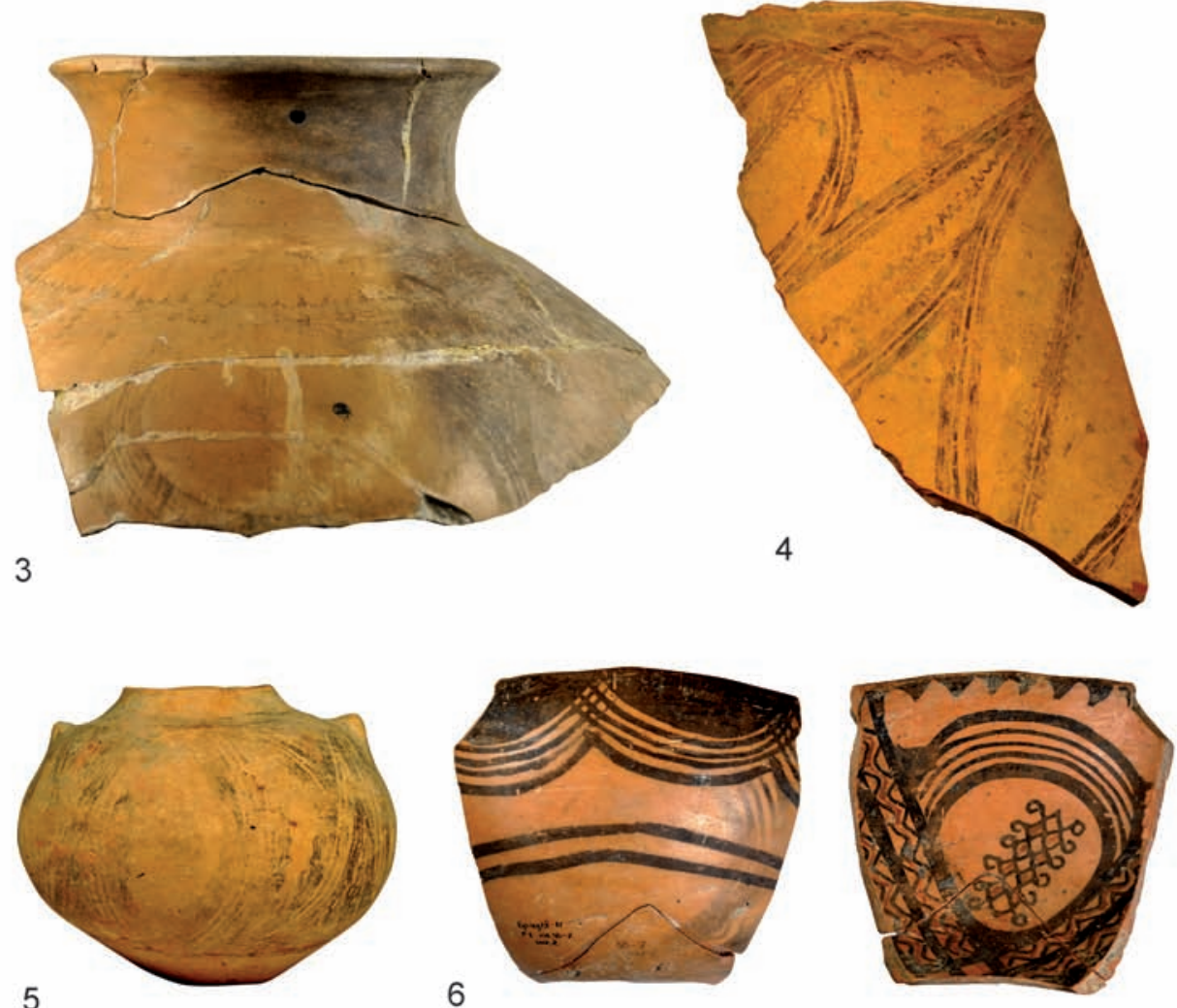

Fig. 26. Brînzeni XI (IX). 1-6 - fine pottery 

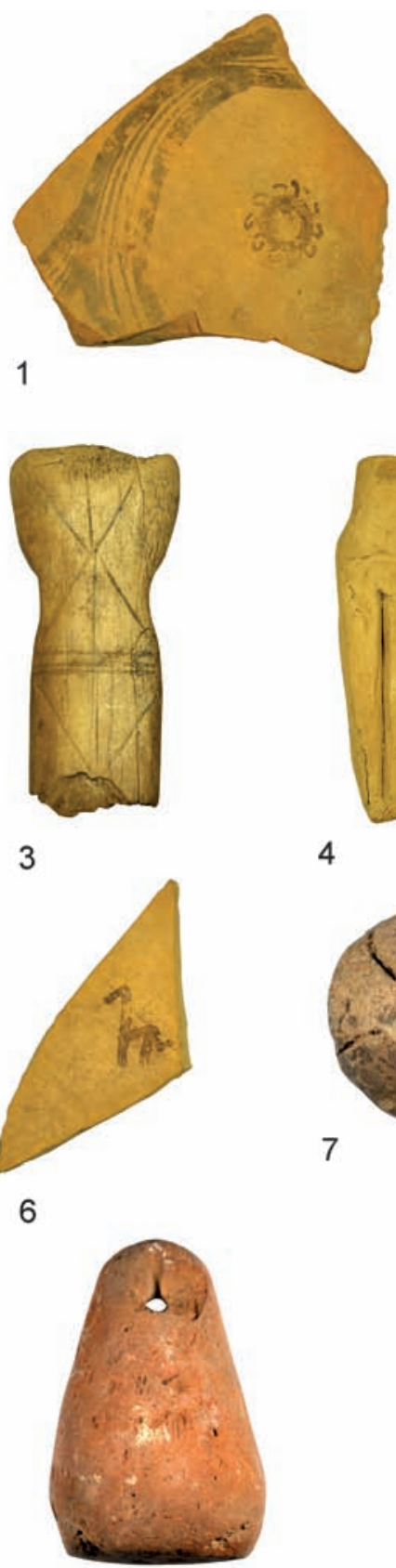

10

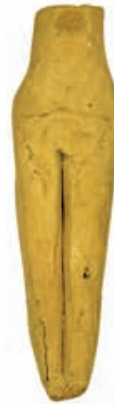

4

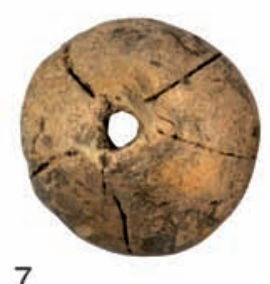

7

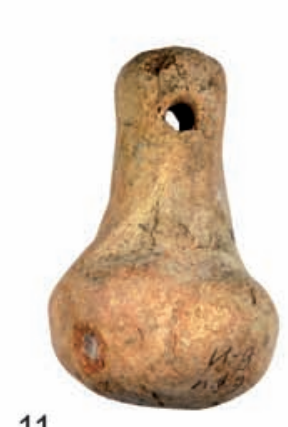

11

5

8
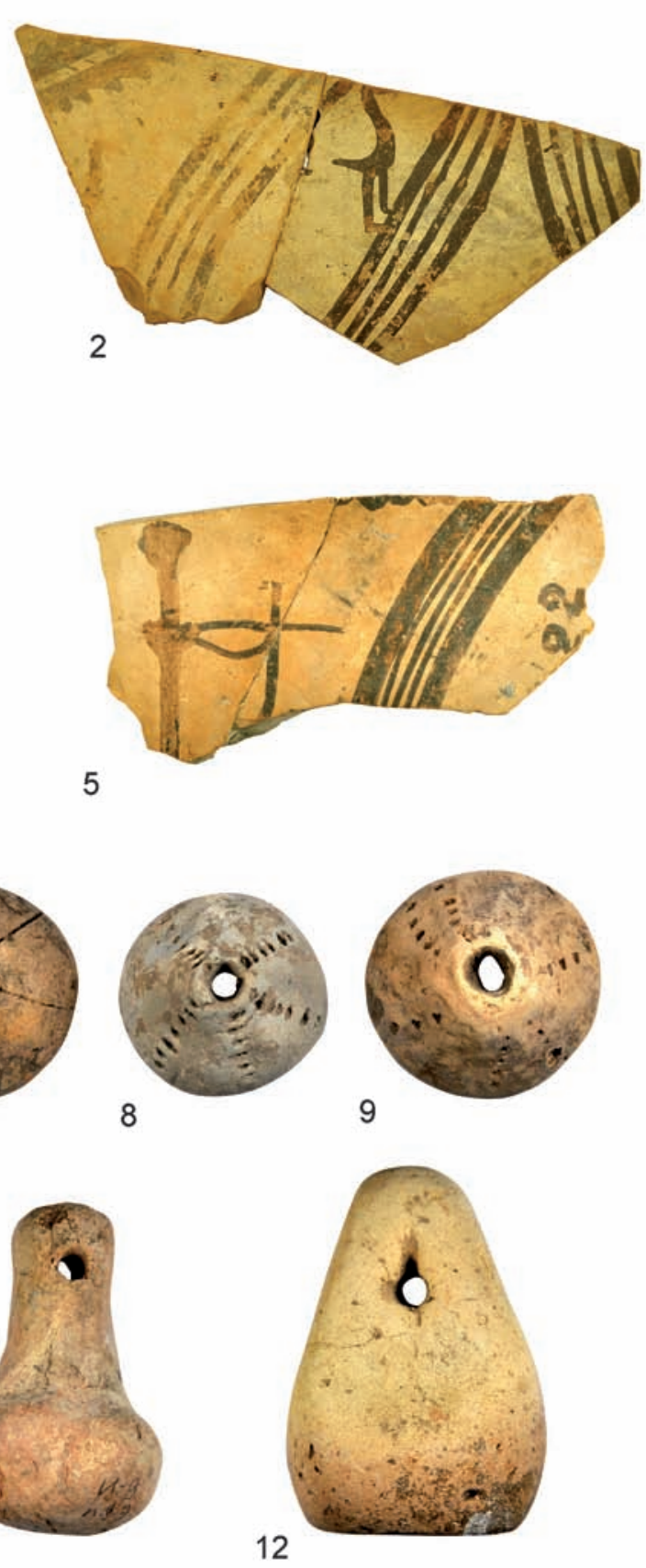

Fig. 27. Brînzeni XI (IX). 1-2, 5-6 - pottery with signs. 3-4, 7-12 - small finds (3 - bone, 4, 7-12 - clay) 


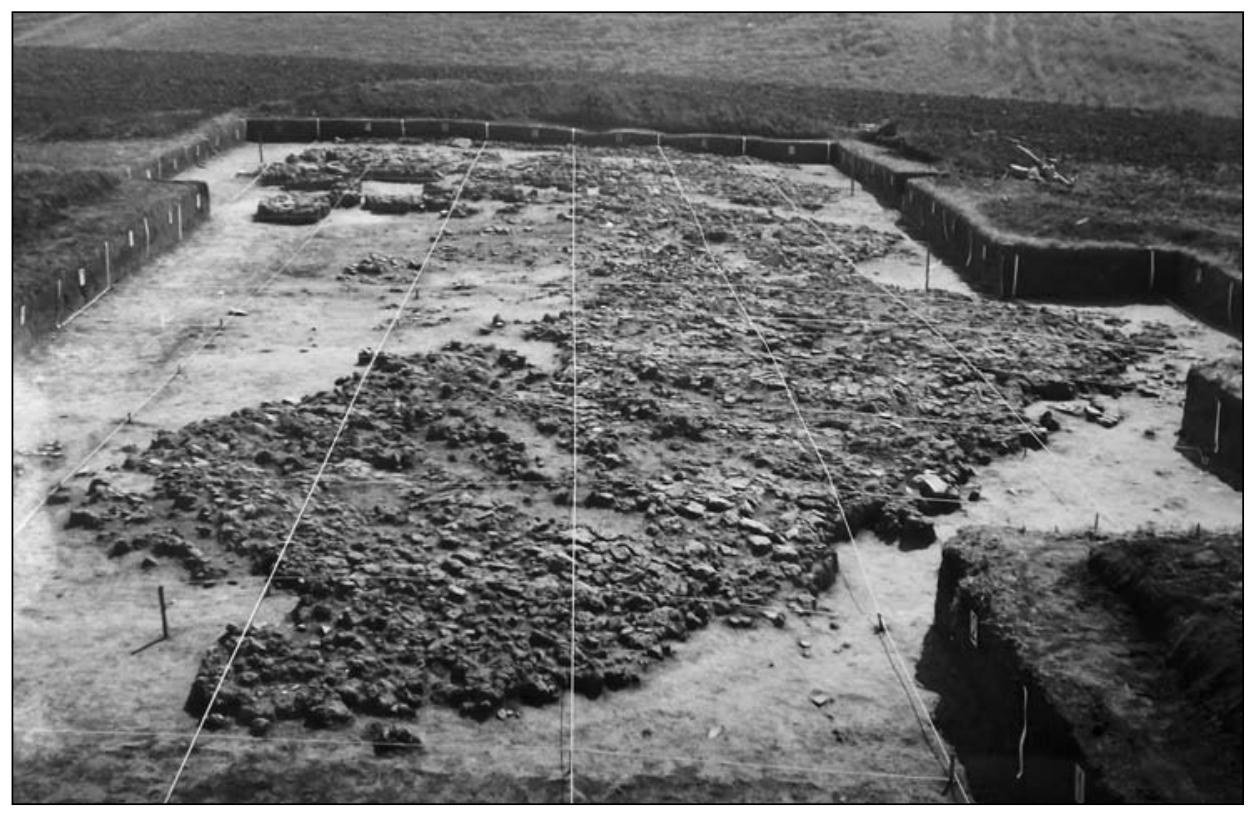

Fig. 4. Brînzeni VIII. Photograph of the dwelling no. 5 from the north. From the field report of V. Marchevici (Markevich 1981a)

Trench no. 5, opened in 1980, contained four dwellings and several pits (Fig. 3). The dwellings generally had a good level of preservation; just dwellings no. 6 and 7 were partly affected by a Sarmatian necropolis from the first centuries AD.

Dwelling no. 5, the largest one investigated on the settlement, was $15 \mathrm{~m}$ long and 5.5$6.8 \mathrm{~m}$ wide, oriented on a SW-NE axis (Fig. 4). The clay platform was well preserved and allowed several interesting conclusions to be drawn regarding the manner of its construction. The wooden ceiling was composed of half-beams, rectangular planks and thinner round timber. Notable are the small hollows with irregular profile on the surface of the burnt daub above the wooden structure. These have been interpreted as rests from pressing in the clay with bare feet during the construction of the house. The clay was successively pressed over the wood deck in a manner similar to the one recorded in Moldavian villages in the mid-20 ${ }^{\text {th }}$ century (Markevich $1981 \mathrm{a}, 5$ ). Judging by the imprints on the clay, the bark was usually removed from the beams. Remains from an oven have been recorded on the ground floor. The inventory of the house consisted of disparate pottery fragments, figurines, a token, a zoomorphic vessel and a large amount of stone and bone implements including 80 coarsely faceted cores from local flint.

Dwelling no. 6 was located to the south of dwelling no. 5 and had a different orientation, on the SE-NW axis (Fig. 5). The ceiling of the ground floor was composed of three 


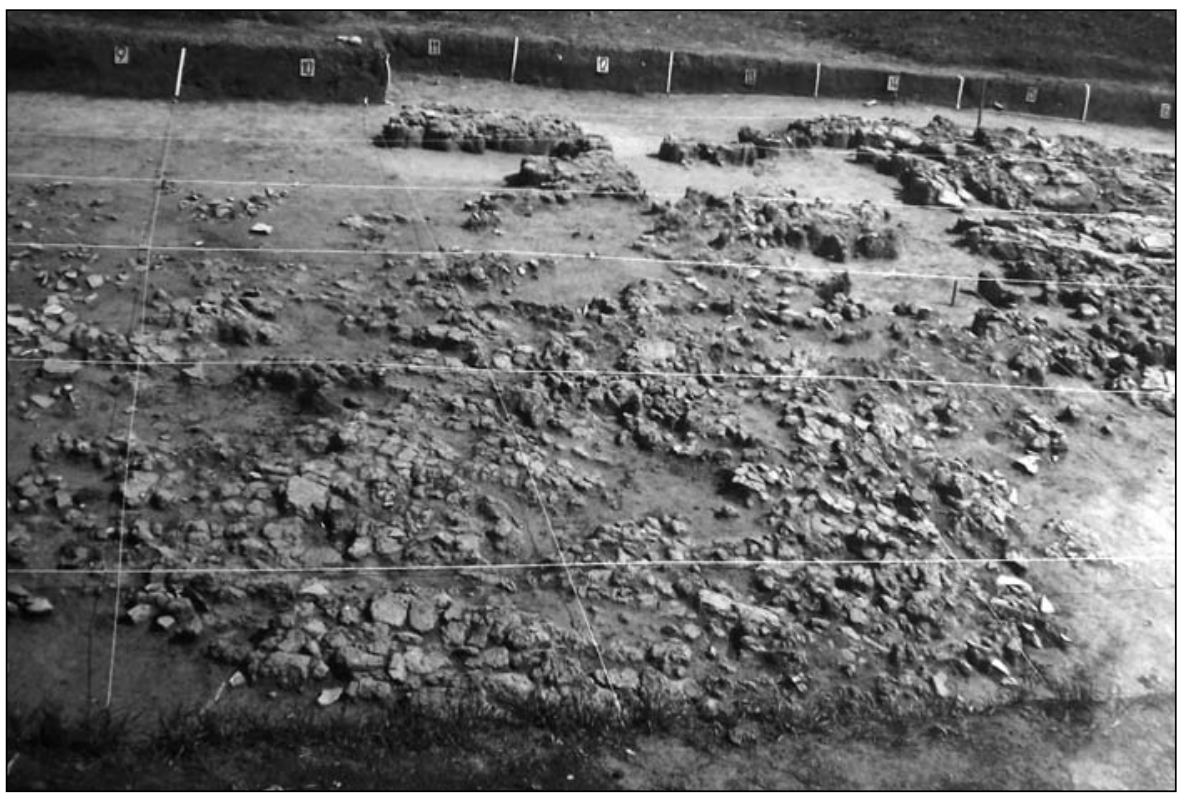

Fig. 5. Brînzeni VIII. Photograph of the dwelling no. 6 from the west. From the field report of V. Marchevici (Markevich 1981a)

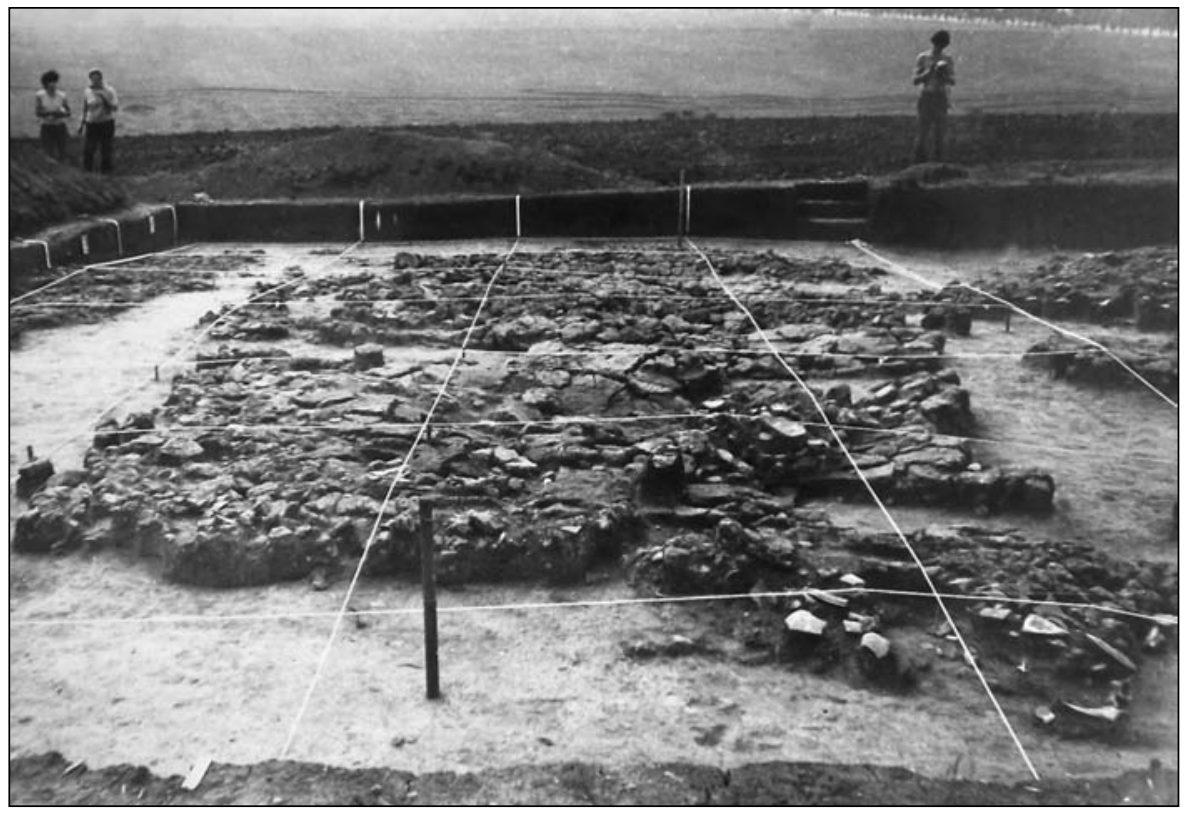

Fig. 6. Brînzeni VIII. Photograph of the dwellings no. 7 and 8 from the east. From the field report of V. Marchevici (Markevich 1981a) 
layers - 1: the lower one made of clay with vegetal admixture, applied directly over the wooden deck, 2: the intermediate one consisting of mixed clay which would level the irregularities of the previous layer, and 3: upper thin layer of clay with sand and chamotte. On the upper floor remains of a construction of an unknown function have been recorded. The ground floor did not contain any installations. A pit partly overlapped by the platform was investigated under the north-western part of the dwelling. The inventory of the house consisted of pottery, stone and bone implements.

Further to the south dwelling no. 7 (Fig. 6) was located. It had an East-West orientation with the dimensions of $12 \times 5 \mathrm{~m}$. A round clay installation was unearthed on its upper floor (Fig. 7). On that installation, remains of a badly preserved cruciform "altar" have been found. The ground storey contained two installations and a small pit, dug from the natural floor level. The inventory of the pit included an anthropomorphic figurine painted with raw ochre, a valve of Unio shell containing ochre and a vessel of fine category. The amount of finds in the dwellings was not high.

Dwelling no. 8 was only partially unearthed; most of its area went under the southern wall of the trench. It was conserved for future investigations.

Apart from dwellings, seven pits were investigated in the trench (Fig. 3) with different shapes and orientations. Notable is the pit no. $1+4$ with elongated contour, parallel to the

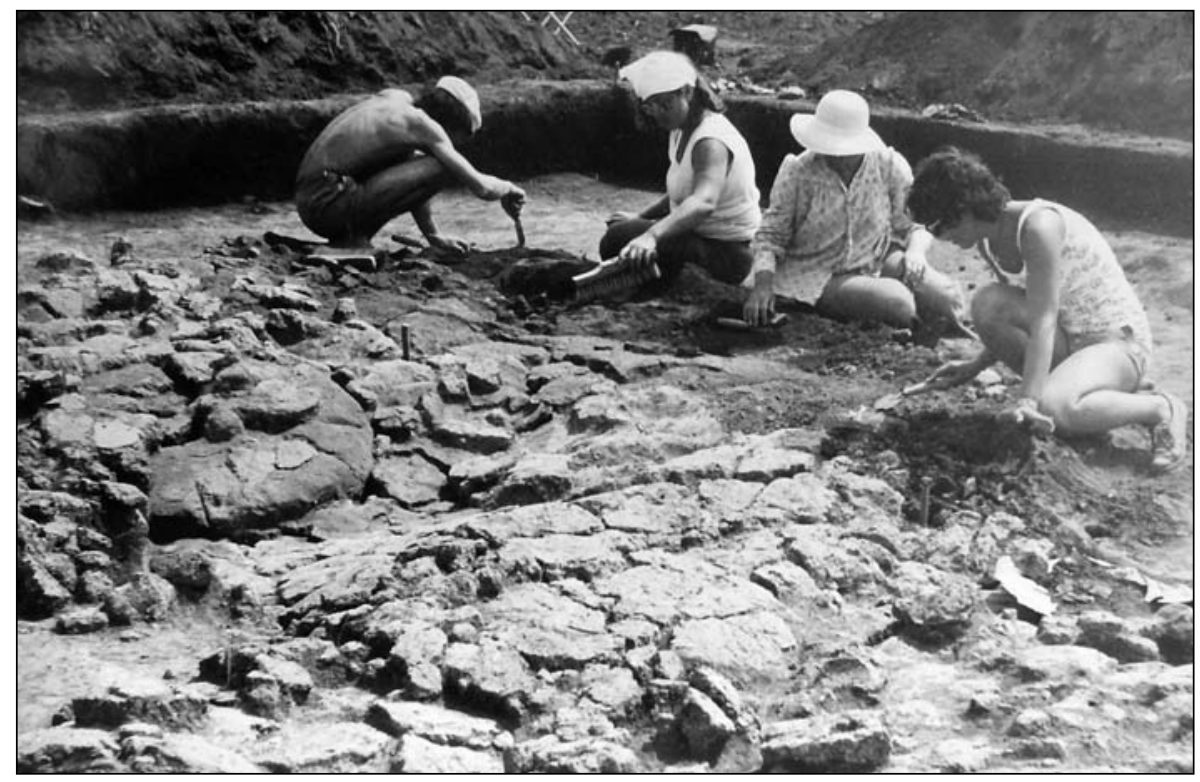

Fig. 7. Brînzeni VIII. The team of archaeologists during the investigation of dwelling no. 7. From left to right V. Bicbaev, L. Polishchuk, T. Todorova, N. Burdo. The rounded clay structure from the upper floor of the dwelling can be seen in the left part of the picture. From the field report of V. Marchevici (Markevich 1981a) 

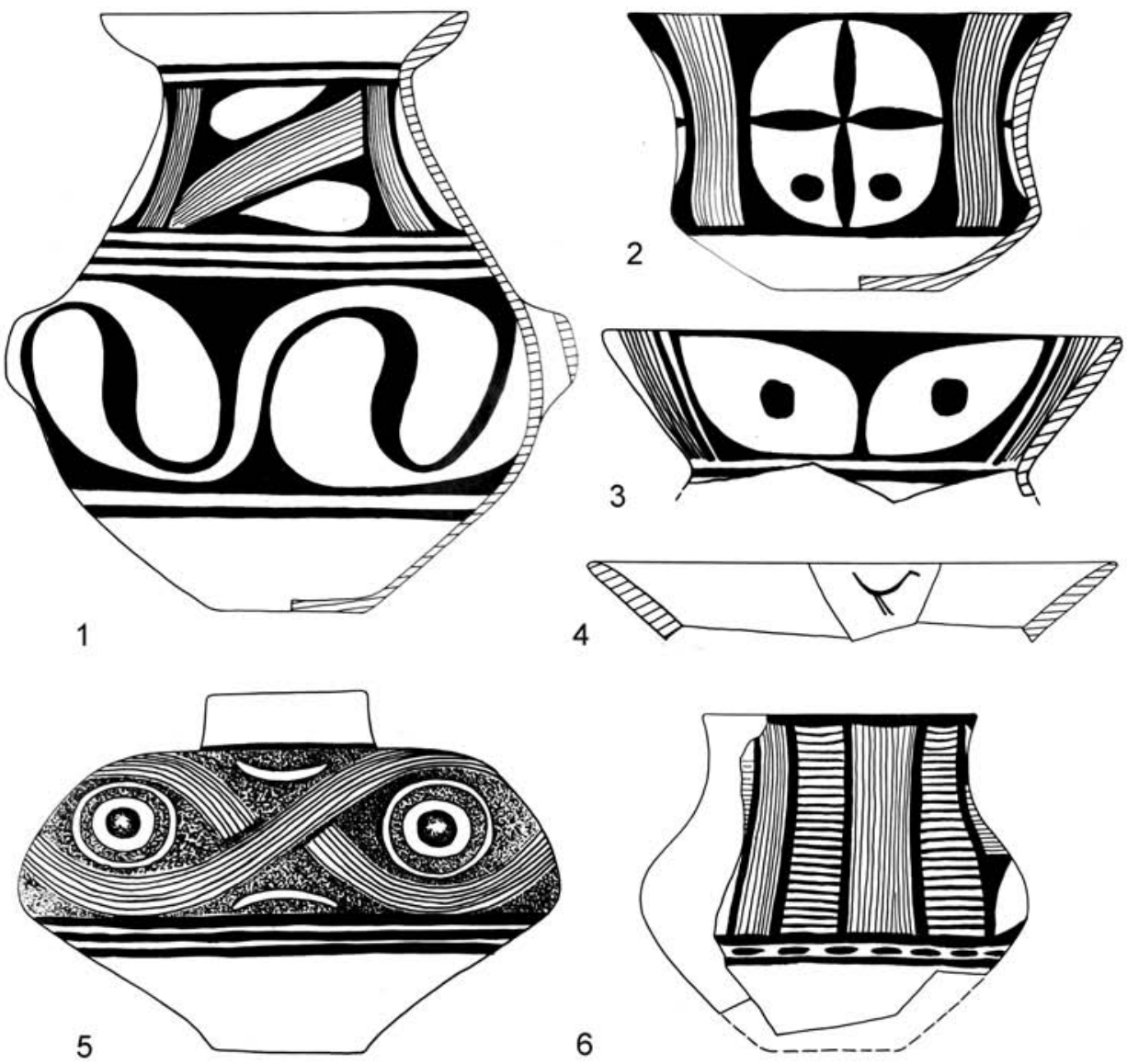

6
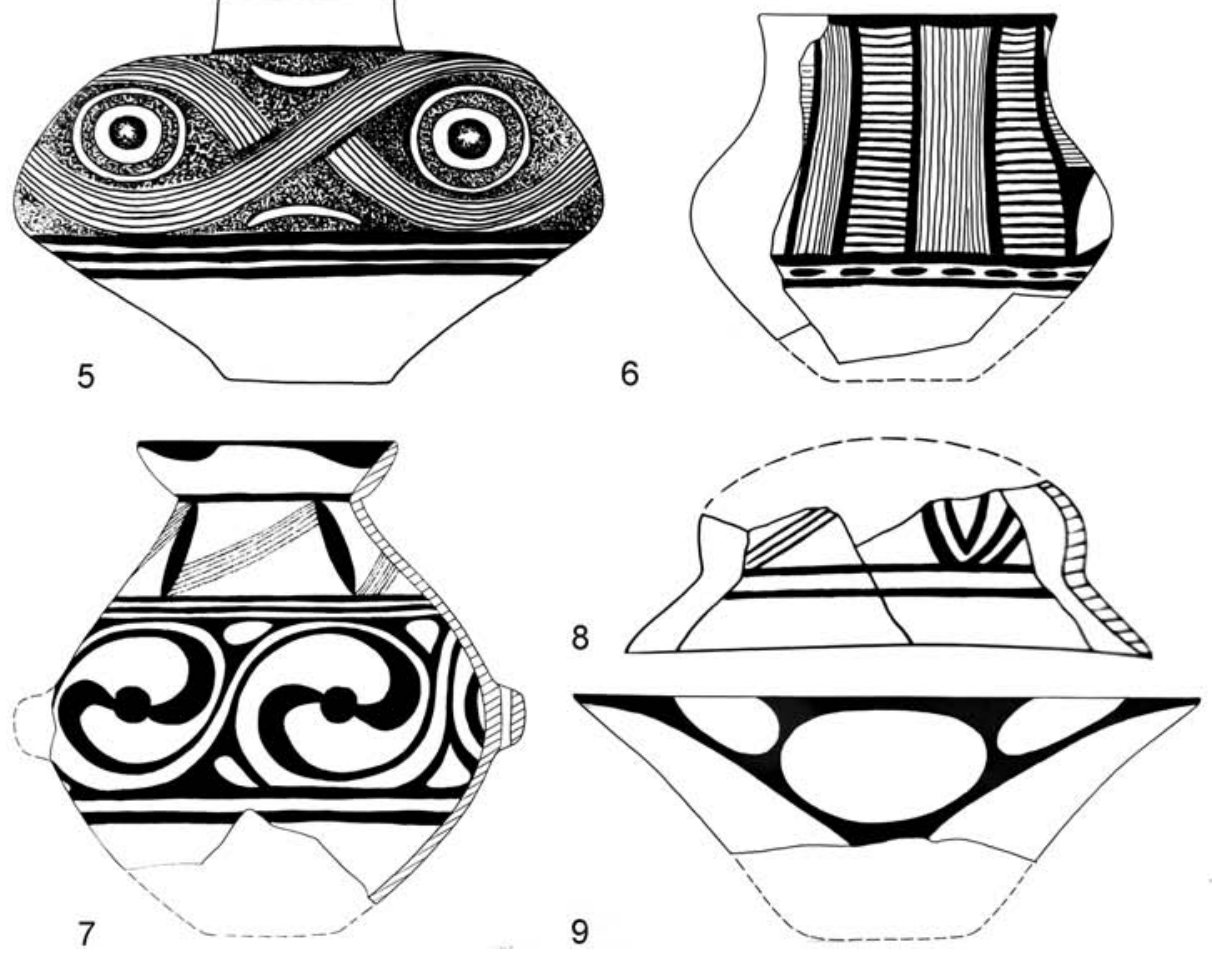

Fig. 8. Brînzeni VIII. 1-9 - fine pottery. From the field report of V. Marchevici (Markevich 1981a) 
Middle and Late Copper Age settlements from the Brînzeni microzone on the Prut river... 305
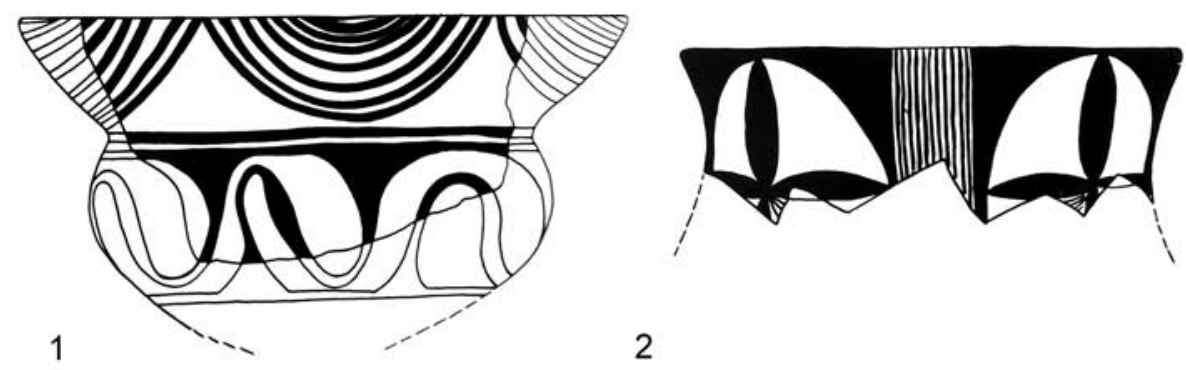

2

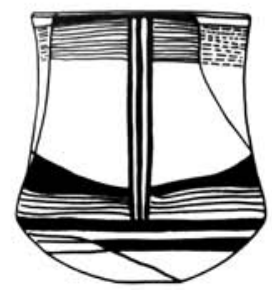

3

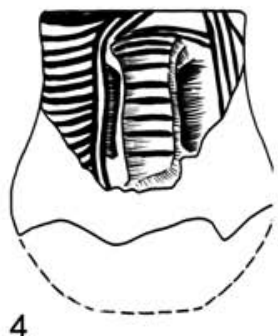

4

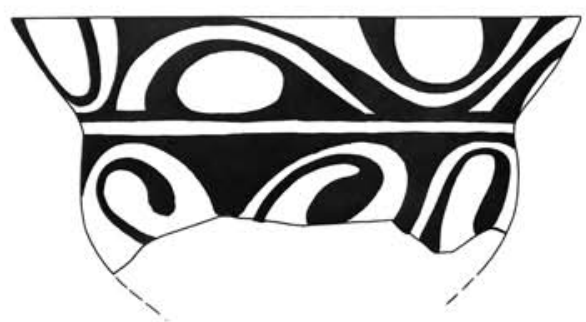

5
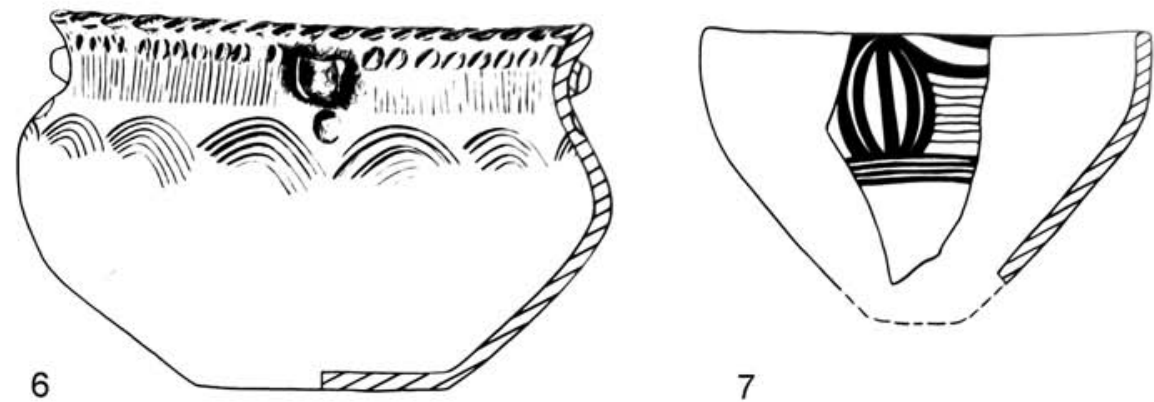

7

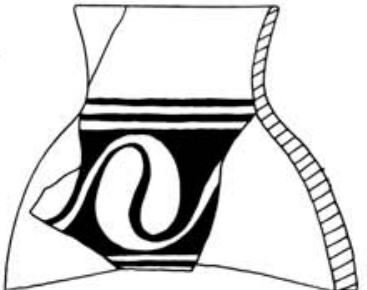

8

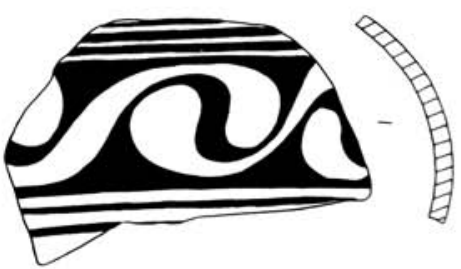

9

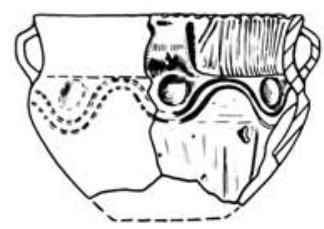

10

Fig. 9. Brînzeni VIII. 1-5, 7-9 - fine pottery; 6, 10 - coarse ware. From the field report of V. Marchevici (Markevich 1981a) 
main axis of the large dwelling no. 5. Previously different sectors of the pit have been interpreted as distinct features, namely pits no. 1 and 4. After further excavation it became obvious that in fact there was a single longer pit, which has been marked as pit no. 1+4. The pit had an irregular bottom and contained many finds. On its bottom, in two of the large shallow cavities, traces of burning have been observed. A part of the pit's bottom at its SW extremity was plastered with clay containing a sandy admixture. The soil under the clay installation was baked to a depth of $4 \mathrm{~cm}$. The pit contained a large amount of finds such as daub pieces, pottery fragments, animal bones, flint implements, many bone and antler artefacts, fragments of anthropomorphic and zoomorphic figurines, miniature vessels with ochre. Most probably, the pit was used to extract the clay for construction of dwelling no. 5 and afterwards used as place for refuse deposition. Traces of burning and the clay installation on its bottom show that the pit could have served as temporarily living facility or a place to perform various household activities. Generally, this pit may represent a distant functional analogy to the Neolithic long pits from South-Eastern and Central Europe.

Interesting is the spiral ornamentation preserved on one of the clay installations from a dwelling (Fig. 11).

\section{Pottery and small finds}

Excavations in Brînzeni VIII provided a large amount of archaeological materials, including over 26,000 pottery fragments, over 1,000 stone, bone, antler and shell artefacts as well as more than hundred of clay miniatures, adornments and various special finds.

The pottery assemblage belongs to two main technological categories, the fine one with little or no admixture and the coarse one with crushed shells in the ceramic paste. Absolute majority of the ceramics refers to first category. Morphologically, several main types can be distinguished, such as pear-shaped vessels, stumpy vessels, vessels with "S"-shaped profile, crater-like vessels, various bowls, cups and lids (Fig. 8: 1-9; 9: 1-3,5,7-9). One cup has a vertical handle (Fig. 9: 4). Stylistically, black is the main ornamental color, often associated with red, seldom - with white color. On several types of vessels, paint was applied on both inner and outer surfaces. The decoration is built of various stripes composed of several parallel lines, spiral patterns, "S"-like bands, round and oval spots, metopes, cruciform compositions built of four ovals supplied by smaller ovals and "S"-like bands, tangent oblique stripes. Representations of birds appear on several fragments and reconstructed vessels (Fig. 8: 4). Pottery of second category is represented by stumpy pots with vertical or slightly deflected neck. Decoration of these pots is composed of incised and impressed patterns including "comb" ornament (Fig. 9: 6,10).

The chipped stone assemblage is built of different kinds of raw material, including the imported so-called "Volhynian" flint. The morphological spectrum includes various tools, most of them made on blades of different dimensions as well as numerous cores and flinthammers. Noticeable is the discovery of a deposit of blades made out of imported flint 
(Fig. 10: 1). Polished stone finds are represented by several axes and multiple complete and fragmented grinders of various functions. One of them bears traces of red mineral (ochre?).

Bone, antler and shell artefacts are diverse, with antler mainly used for production of mattocks. The bone industry is represented by adzes, awls (Fig. 10: 10), polishers and some special finds, such as a pendant (?) with cogged margin (Fig. 10: 5). Notorious is an antler find (pendant?) of a twisted shape with perforations (Fig. 10: 11). A perforated fish vertebra was obviously used as a bead (Fig. 10: 2). Shell artefacts include stamps for pottery ornamentation.

Some finds indicate possible copper smelting on the site. These are represented by fragments from probable melting pots and a typical heavy stone hammer for crushing ore.

Clay miniatures include anthropomorphic and zoomorphic figurines as well as miniature vessels, tokens and balls. The anthropomorphic figurines were published earlier (Sorochin 2001). They are represented by conventionally-realistic female statuettes of different types (Fig. 10: 7-9). Most of them are painted. There are several figurines with cavities in the abdominal part. Images of bovidae prevail in the zoomorphic plastic art, both as figurines (Fig. 10: 6) or vessel parts (Fig. 10: 3-4). Ornitomorphic rattles are also known (Fig. 10: 12).

Noticeable is the imprint of a grape leave on a daub fragment (Fig. 12).

\section{Settlement structure and chronological setting}

As mentioned above, K. Shishkin made aerial photographs of the site in late 1970's. The images obtained allowed him to trace the internal layout of the site with elements of radial and square-like house rows as well as streets (Sorochin 1993). The comparison of Shishkin's interpretation and modern satellite imagery (Fig. 2) shows the limits of the Copper Age occupation and the outline of a probable inner (older?) ditch. Radial centripetal rows are clearly observable in the central part of the site, while the northern and southern periphery may have a different layout.

In terms of relative chronology, the settlement belongs to the Meresseuca group of the Cucuteni B - Tripolye B2 stage. This local variant has been identified by V. Sorochin and includes the intermediary sites between Tripolye B2 and C1 stages. Apparently, Mereşeuca sites are the ones behind formation of settlements of Stolniceni and Petreni type (cf. Sorokin 1990).

One radiocarbon date made on charcoal is available for the site (Fig. 13). We should mention that this date, both BP and calibrated (calibration done with the OxCal program, version 4.3., working with IntCal 13 curve - Reimer et al. 2013), does not correspond well with the Tripolye $\mathrm{B} 2 / \mathrm{C} 1$ relative-chronological sequence and is too high, reaching the time span of the early Cucuteni A-B - Tripolye B1-B2 stage. In fact, this date would rather fit with the Middle Tripolye layer from the Brînzeni IV settlement (see below). Unfortunately, the original publication of the dates from Brînzeni VIII and IV does not contain any detailed information on the archaeological context of the samples (Wechler 1994). We would 
therefore not exclude the possibility that the sampled charcoal assigned to Brînzeni VIII settlement in fact comes from the lower horizon of Brînzeni IV site.

\section{Perspectives for future research}

Further investigations of Brînzeni VIII settlement may be of crucial importance for understanding the appearance and formation of large Cucuteni-Tripolye settlements from the Prut and Dniester interfluve. Beside the processing and publication of older research of V. Marchevici, the geophysical prospection of the settlement is absolutely necessary, as is obtaining ${ }^{14} \mathrm{C}$ data from secure contexts. The proximity of Brînzeni VIII to such Tripolye C1 sites as Trinca (which is located higher on Draghişte river) and Stolniceni I, for which we know the internal layout (Hofmann et al. 2016; Țerna et al. 2016), will allow the tracing of similarities and differences of the structure of larger Tripolye sites within a relatively small region while the analysis of pottery and absolute dating shall provide good chronological background for investigating the dynamics of the process of evolution of complex sites.

\section{BRÎNZENI IV - "TÂRLA LUI ŞTEFAN"}

\section{Site location, stratigraphy, description and history of research}

The settlement lies on the eastern outskirts of Brînzeni village, on a promontory flanked on three sides by hard accessible slopes and rocky cliffs. The local name for that promontory is "Târla lui Ştefan". The area of settlement is circa 17 ha and the settlement's stratigraphy is composed of a Cucuteni A/A-B - Tripolye B1-B2 layer, a Cucuteni B - Tripolye C1 layer, stray finds of Tripolye $\mathrm{C} 2$ stage and Roman time graves.

The site was discovered in the 1970's by V. Marchevici. In 1977, the same archaeologist investigated two Cucuteni B - Tripolye C1 dwellings in its southern part. Four years later, a pit from the A/A-B - Tripolye B1-B2 occupational horizon was researched. Information on the 1977 excavations is limited to the brief description from Marchevici's monograph on the Late Tripolye communities of Northern Moldova (Markevich 1981); other information, like field reports and documentation, is missing. The 1981 investigations are unpublished and are described in the original field report from the Archive of the National Museum of History of Moldova (Markevich 1982). Few selected finds from both campaigns have been published in a catalogue (Markevich 1985).

\section{Cucuteni B - Tripolye C1 archaeological features}

A description is available for only one of the excavated dwellings (Markevich 1981, 14-16).

Dwelling no. $1(14 \times 5 \mathrm{~m})$, oriented on the SW-NE axis, was a two-storey one and was well-preserved. The ground floor had two rooms. Each of them contained an oven with the 
dimensions of $1.2 \times 1.2 \mathrm{~m}$, constructed of successive clay bands. Remains of the plastered floor have been preserved in several places. The floor was built out of two or three successive plaster layers, each of them 1-1,5 mm thick. The composition of plaster included sand and chaff.

Of special interest are the oven and the adjacent inventory from the south-eastern room. The oven had a square shape with rounded corners. A rectangular hearth adjoined from the south-west. Just next to the oven, two biconical cups have been found, each containing a complete anthropomorphic figurine. In the same area, a large vessel was dug into the earth. On its bottom, remains of charred grains of barley and hulled wheat have been discovered. Nearby, on the floor, a second large biconical vessel was found. Further to the south-west seven more biconical and pear-shaped vessels were located. In front of the oven's opening a small pit with the depth of $0.6 \mathrm{~m}$ was investigated, containing several vessels painted with black and red.

A pit with the diameter of $0.9 \mathrm{~m}$ and depth of $1.3 \mathrm{~m}$ was located in the north-western room. It was filled with fragments of daub with imprints of chopped wood and reed. Two complete biconical vessels, several other shards and fragments from an anthropomorphic figurine have been found in the pit.

Besides pottery, the ground floor contained flint implements, bone tools, clay tokens and fragments of figurines.

The floor of the upper storey was made of a $5 \mathrm{~cm}$ thick layer of clay with chaff admixture ("platform)" spread over a wooden ceiling which was built of halved beams laid across the main axis of the dwelling. The beams had various profiles and width (from 12 to $24 \mathrm{~cm}$ ). Above the main clay layer, a thin layer of plaster was applied, made of clay with chamotte admixture.

On the floor of the upper storey, near the south-western extremity of the dwelling, a square-shaped raised installation was located, made of three layers of clay with chamotte, each 2.5-3 cm thick. Probably, this structure served as basis for an oven. On the floor, next to this raised area, biconical and pear-shaped vessels of different dimensions have been found, associated with helmet-like lids and fragments of coarse ware.

Most probably, the upper storey had a wooden roof ceiling coated with clay containing a chaff admixture. Often, on the perimeter of the clay platform, fragments of burnt daub with imprints of rods have been noticed. These may represent the remains of walls, erected on a wooden frame.

\section{Cucuteni B - Tripolye C1 pottery and small finds}

The excavations in Brînzeni IV yielded a large collection of pottery and other artefacts (cf. Markevich 1981, 16-18; 1985, 78-79).

The pottery belongs to two main technological groups - fine ware, with little or no visible admixture, and coarse ware, with admixture of crushed shell. The spectrum of shapes 
of fine pottery is typical for Cucuteni B - Tripolye C1 stage of Prut-Dniester region and includes biconical and spheroconical vessels with a deflected rim (Fig. 14: 1-2, 4), pearshaped stumpy vessels with the neck bent inward, biconical cups (Fig. 14: 3, 5) and vessels with no prominent rim, helmet-like lids (Fig. 14: 6-8) and truncated bowls. Fragments from bowls on four legs (so-called "backets") are also known. The ornamentation is applied with black or dark-brown paint, often associated with red. Stylistic patterns and motifs include spirals, strips of parallel lines, sinusoids, zigzags, festoons, circles with crosses. On a large vessel two ornitomorphic figures are represented (Fig. 14: 2). On several vessel bottoms, textile imprints are visible. The vessels of the coarse category are rather stumpy, with an oval body and vertical rim. Small handles are usually placed under the neck. The decoration includes various incised and impressed patterns (Fig. 15: 6-7) combined with "comb"-like ornamentation.

The small find assemblage consists of diverse items made of clay, stone, flint, bone and antler. Clay artefacts are represented by anthropomorphic (Fig. 15: 1-3) and zoomorphic figurines, weights, spindle whorls (Fig. 15:4) tokens and miniature balls. Stone finds include various grinders and polished adzes. The flint industry is composed mainly of blades and scrapers of different types. Bone and antler artefacts are not numerous and display several types - an adze (Fig. 15: 5), a polisher, awls and a mattock.

\section{Cucuteni A/A-B - Tripolye B1-B2 archaeological features}

A single pit from this horizon has been investigated (Markevich 1982, 104-116). It was discovered by chance in 1981 during the investigations on the Brînzeni XI (IX) settlement (see below), located on the opposite side of the valley. Visual observation of the cliffy edge of an area affected by a landslide allowed the archaeologists led by V. Marchevici to observe the ashy spot of a pit which was subsequently excavated. The pit had a rounded horizontal outline and a pear-shaped profile. Its depth reached $189 \mathrm{~cm}$ from the presentday surface and its maximal diameter was $212 \mathrm{~cm}$. The fill consisted of an ashy grey soil with tiny charcoal inclusions.

\section{Cucuteni A/A-B - Tripolye B1-B2 pottery and small finds}

The inventory of the pit included fragments from 23 fine vessels and three antler tools. The vessels have been ornamented with mono-, bi- and trichrome paint on different types of engobe (Fig. 16: 1-5). Stylistic elements consist of various stripes, spirals and hatches. The morphological spectrum includes pear-shaped vessels, truncated spherical bodies, a "binocular" vessel, cups and several other types.

All three antler artefacts represent mattocks - one finished and two semi-finished. 


\section{Settlement's structure and chronological setting}

Because of limited excavations, there are no data regarding the settlement's structure. To a certain extent, features of distinct chronological horizons (Cucuteni A/A-B and Cucuteni B) may overlap each other. There is no certainty regarding the type of occupation in the later C2 stage - there are reported finds but no archaeological features.

There is a radiocarbon date for the Cucuteni B - Tripolye $\mathrm{C} 1$ layer, made on charcoal (Bln-2430, cf. Wechler 1994, 16). Calibration of the BP date (done with OxCal program, version 4.3., working with IntCal 13 curve - Reimer et. al. 2013) situates the settlement within the chronological range of 3958-3695 cal BC, with 95.1 \% probability (Fig. 17). It is noteworthy that this date corresponds perfectly to the dating of large Stolniceni I (Țerna et al. 2017) and Petreni (Uhl et al. 2016) settlements, investigated in recent years. From a relative-chronological point of view, the Brînzeni IV settlement would represent the start of the Tripolye $\mathrm{C} 1$ stage in the Prut region.

According to the ceramic typochronology, the pit investigated in 1981 can be attributed to the end of Cucuteni $\mathrm{A}_{4}$ - beginning of Cucuteni A-B stage and would generally correspond to the sites of Solonceni type from the Dniester basin (see Sorochin 2004). In absolute-chronological terms, this stage can be roughly dated to the beginning of the last quarter of the $5^{\text {th }}$ millennium BC (see also Weninger and Harper 2015, 487).

\section{Perspectives for future research}

Apart from find processing and exhaustive publication (which is a complicated task due to the loss of field documentation), geomagnetic prospection of the site with testtrenching of various anomalies in order to date different sectors of the plot is necessary, as well as obtaining new radiocarbon data from distinct horizons of settlement's occupation in the Copper Age. Further evaluation and investigation of the Cucuteni B - Tripolye C1 horizon is of special interest due to the territorial proximity to the Stolniceni I settlement.

\section{BRÎNZENI IX - "MERSÂNA”}

\section{Site location, stratigraphy, description and history of research}

The settlement is located at a distance of circa $3 \mathrm{~km}$ to the west of the modern-day village, on the high rocky left bank of Draghişte river, at an absolute height of around $150 \mathrm{~m}$ above sea level and a relative height of $50 \mathrm{~m}$ above the river. It was discovered by V. Marchevici in 1970 (Markevich 1973, 61). The area of the site does not exceed 1.2 ha and can be assigned to Tripolye $\mathrm{C} 2$ stage; according to $\mathrm{V}$. Bicbaev, who later collected ceramic material from its surface, the site could be connected with the Chirileni (= pre-Gordineşti) local group (we would like to thank V. Bicbaev for this information). 


\section{Archaeological features and discoveries}

No archaeological excavations have been made on the settlement. Nevertheless we decided to include it in this article due to an interesting discovery, made by a local inhabitant on the slope near the site - namely the find of a copper adze-axe (Fig. 18), completely preserved (Markevich 1981, fig. 54: 1). Morphologically, it can be attributed to the wide-spread Jászladány type (cf. Manzura 2003, table 1, 399-407). According to I. Mareş (Mareş 2012, 167-182), the lower chronological limit for distribution of Jászladány axes in the Cucuteni-Tripolye would be Cucuteni B - Tripolye C1 stage; thus, the axe from Brînzeni, dated with Tripolye $\mathrm{C} 2$ period, would represent one of the latest finds of such type. It should be stressed that outside of the Cucuteni-Tripolye area, several Jászladány axes have also been linked to Final Copper Age Coțofeni settlements (Mareş 2012, 178-179), so the persistence of this type in Tripolye $\mathrm{C} 2$ stage should rather not be seen as surprising.

\section{Perspectives for future research}

Further investigations of the site, including geophysical prospection and test-trenching, will be important both for research of the Copper Age settling of the Brînzeni microzone and refining the chronology of axes of the Jászladány type.

\section{BRÎNZENI III - "ȚIGANCA”}

\section{Site location, stratigraphy, description and history of research}

The settlement was located on a cupola-like rocky hill at a distance of $1.5 \mathrm{~km}$ to the NW from the village. The hill was naturally protected from three sides while the southern access was probably reinforced by a ditch. The absolute height of the hill is about $180 \mathrm{~m}$ above sea level and the relative one - circa $50 \mathrm{~m}$ above the water level of the Racovăț river.

The site was discovered in 1968 by N. Chetraru. In 1970-1972, an expedition led by V. Marchevici excavated the complete available area of the hill, which started to be destroyed for stone extraction. Thus, about one third of the settlement's area of circa 1.5 ha has been destroyed and the remaining part comprising 37 above-ground dwellings has been investigated (Fig. 19). The settlement therefore represents one of the most completely investigated prehistoric sites from the Prut - Dniester interfluve.

Unfortunately, most of the materials remained unpublished. A general overview of the site and its most interesting finds was made in Marchevici's synthesis of the late Tripolye communities of Northern Moldova (Markevich 1981, 33-42). Also, certain finds have been included in several catalogues (Stratulat 2008; Stratulat 2009; Markevich 1985).

Brînzeni III has been considered eponymous for defining the Brînzeni local group within the Tripolye C2 chronological stage (cf. Dergachev 1980, 111-119; Manzura 1994, 
105-106). Despite the importance of the settlement and its inventory, the brief information from the monograph of Marchevici still remains the main source of information for the excavated features and finds. The situation became even worse with time, when most of the original field documentation has been lost. Today, a systematic approach to re-evaluation and final publication of the settlement has to be performed by taking into account the problems mentioned above.

\section{Archaeological features}

As mentioned above, 37 houses have been investigated. The dwellings were erected directly on the calcareous rock. Some of them have been additionally consolidated with soil banking. Most of the houses were two-storey ones, of rectangular or - seldom - square shape, with the dimensions of 30-62 $\mathrm{m}^{2}$.

After first cleaning, the dwellings looked like rectangular piles of burnt clay, consisting of two distinct layers. The upper 3-4 cm thick layer was built of "tiled" clay with an admixture of sand and small chamotte. On the perimeter, this layer pinched out upwards, indicating that the clay was smoothed by hand towards the walls of the dwelling. The lower layer was thicker and represented clay with an admixture of chaff applied over the wooden frame of the ceiling (half-beams and timber). The ground floor consisted of clay spread directly on the surface of the rock. Particularly interesting is the find of a rectangular empty area with smoothed margins in the ceiling of one of the dwellings. According to V. Marchevici, this feature could represent the remains of an aperture designed for a ladder leading from the ground to the upper storey.

Various internal installations, such as fireplaces, ovens, "altars" and grinding places have been recorded. The ovens were domed with a rectangular layout. The corners were rounded. To the left of the oven's mouth a small pit was used for keeping the fire. All of the oven's walls were constructed of successive clay bands. Field observations allowed V. Marchevici to conclude that the oven frames were modeled outside of the dwelling and afterwards mounted inside.

In several cases remains from internal walls have been documented. A typical Brînzeni III dwelling is presented in the figure no. 20.

\section{Pottery and small finds}

The pottery represents the most numerous find category and has mainly been collected from the inventory of dwellings. Technologically, it belongs to the typical late-Tripolyan groups, namely the fine ware made out of clay with little or no admixture and the coarse ware made out of clay with crushed shell and - rarely - chamotte. Fine ware represents about $65 \%$ of the whole assemblage. 


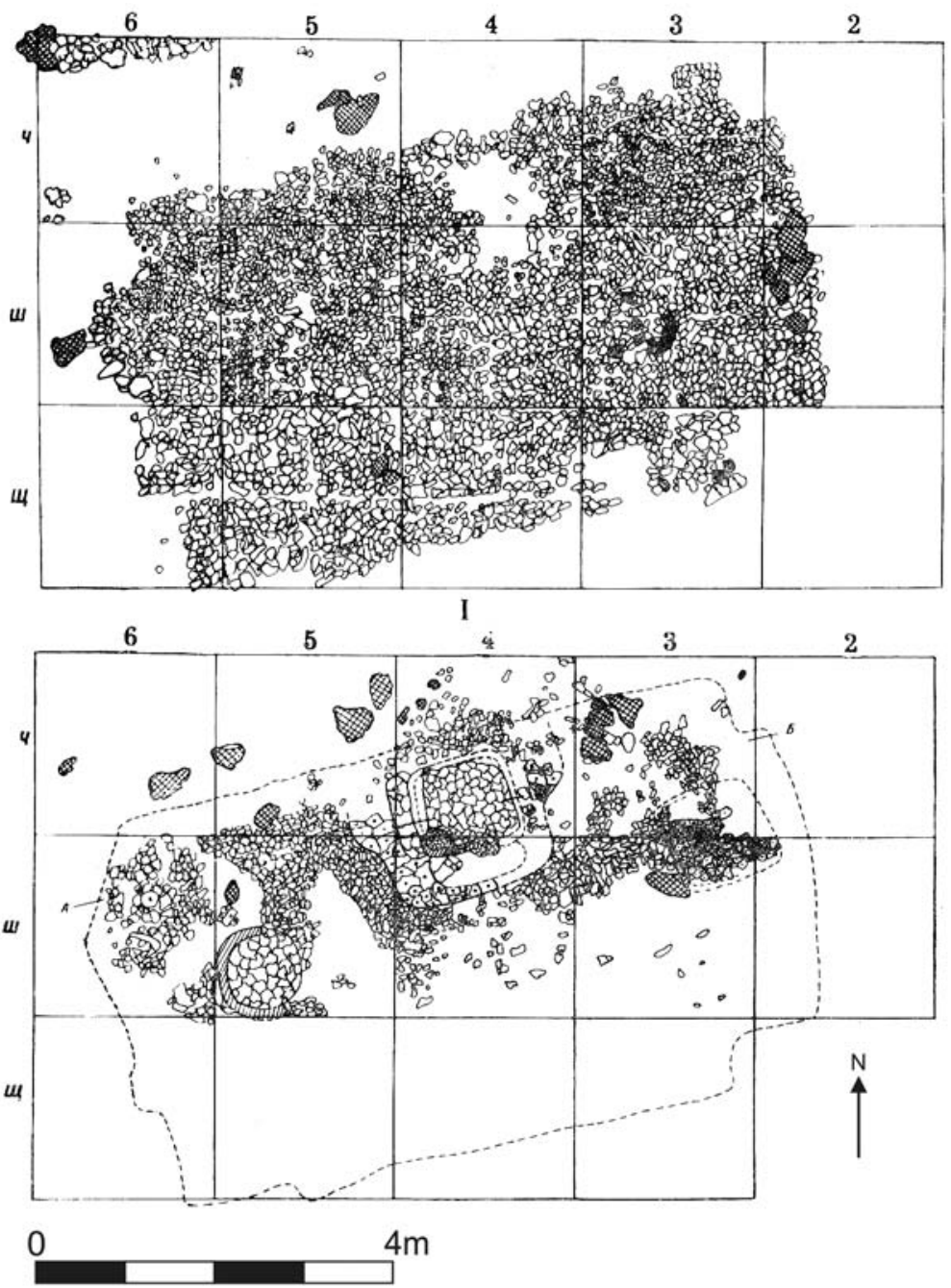

Fig. 20. Brînzeni III. Plan of a typical dwelling (no. 25). Up - upper floor, down - ground floor

Morphologically, fine ware includes several vessel types, such as vessels with a spherical body and straight, deflected or slightly inflected rim, pear-shaped vessels and amphorae with small "ears" under the neck, crater-like vessels, napiform vessels with high neck (Fig. 21: 3), various types of bowls and lids. Characteristic is the presence of numerous vessel bottoms with textile or rope imprints (Fig. 21: 4-5). The decoration is applied mainly with dark-brown or black paint, sometimes associated with red one. Ornament is built in several layers and is composed of ovals with tangents, festoons, bands consisting of parallel lines, zigzags, W-, M- and V-like patterns. 
One of the most outstanding features of the ceramic assemblage are the numerous painted anthropomorphic and zoomorphic representations; in fact, the collection of painted human figures from Brînzeni III is by far the largest from a single site of the Cucuteni-Tripolye culture. The painted human figures are presented in various contexts and scenes (Fig. 22) - single or in pairs, associated with animals. Notable is the hunting scene on one of the pottery fragments.

Coarse ware includes vessels with globular body and small conical buttons on the shoulders. The pottery is ornamented with impressions, incisions or corded decoration (Fig. 21: 2).

Of special importance for the problem of relative chronology and distant relations of the Brînzeni group are the finds of imported pottery assigned to the Bodrogkeresztúr and Funnel Beaker (Fig. 21: 1) cultures (Titov and Markevich 1974; Markevich 1981, 176-182; on the Tripolye - Funnel Beaker contacts in the Tripolye C2 stage, e.g. Videiko 2000, 43-47).

Small finds include artefacts made of stone, bone and antler, clay and copper.

Chipped stone assemblage is built of two kinds of raw material - local and imported. The tool spectrum includes various blades and scrapers as well as hammers (Fig. 23: 6), arrowheads and javelin-like implements. The polished stone category consists of axes (Fig. 23: 5) and grinding tools.

Large and diversified is the bone and antler industry. Bone artefacts include awls, polishers and tools for scraping leather as well as a group of daggers (Fig. 23: 9). Antler artefacts include hammers, mattocks, battle axes and other tools (Fig. 23: 7-8,10). The planigraphy of antler finds shows a rather homogenous distribution within the dwellings from the settlement, with the exception of dwelling no. 17, which contained 53 items.

Noteworthy is the discovery of an astragali deposit in a painted vessel from one of the dwellings. All 15 knucklebones from the deposit have traces of burning (Fig. 23: 4).

The clay finds include miniature vessels, several schematic (Fig. 23: 1) and one realistic (Fig. 24: 2) anthropomorphic figurines, many spindle whorls and weights (Fig. 23: 3).

Copper industry includes an adze (Fig. 23: 11) and a chisel.

\section{Settlement structure and chronological setting}

Thank to the large-scale excavation, the settlement layout was able to be reconstructed, even though one third of the site has been destroyed. The plan of the settlement (Fig. 19) shows a rather irregular internal structure with some rows and groups of houses. A larger dwelling seems to be located in the center of the investigated part. In general terms, such a layout fits with the still few available Tripolye $\mathrm{C} 2$ settlement plans from the Prut-Dniester interfluve, obtained as a result of excavation (Costeşti IV - Markevich 1981, fig. 66) or recent geomagnetic prospections (like on the settlement Cunicea III - unpublished prospection of Țerna and Hofmann in spring 2016, for brief information see Țerna 2016; Hofmann et al. 2016). 
According to a short note (Markevich 1987), another independent part of the settlement stretches under the rocky hill, on the valley located immediately to the south. The area of this low unfortified sector would represent about 7 ha.

Chronologically, the Brînzeni III site (and the Brînzeni group) refers to the Tripolye C2 stage, preceding the sites of Gordineşti type. In terms of absolute dating, despite the lack of 14 data, it can be assigned to the interval of 3550-3300 cal BC (Diachenko and Harper 2016, fig. 3).

\section{Perspectives for future research}

Despite the huge lacunae in field documentation, the Brînzeni III settlement still offers excellent perspectives for further investigations. Apart from the systematic processing of older collections and complete publication of available information, of great interest will be refining its chronology by means of radiocarbon dating of samples from various house groups and the archaeological investigation of the lower (intact?) part of the settlement, including geophysical prospection and small-scale excavation which would allow us to check the relation between the both sectors of the same (?) site.

\section{BRÎNZENI XI (IX) - "VALEA BUCŞII"}

\section{Site location, stratigraphy, description and history of research}

The settlement is located on the south-eastern periphery of the village, on the left side of the Bucşa river (affluent of Racovăț river), on a promontory built by a bend of the river outline. It was discovered by V. Marchevici in 1976. The settlement's area is circa 5 ha.

Initially, in 1976, the site was given the name "Brînzeni IX". This was, however, in contradiction with the already existing corpus of Copper Age settlements in the outskirts of Brînzeni village (Markevich 1973), where Brînzeni IX was alocated to the "Mersâna" settlement (see above). That is why here we will use the "Brînzeni XI (IX)" name, following the corpus of V. Bicbaev.

Archaeological investigations were begun in 1977 by V. Marchevici, who opened a trench on a burnt house. The trench was subsequently conserved and re-opened in 1981, allowing the researchers to investigate two dwellings and a pit (Melnichuk 1982). A second trench was opened in the same year by an expedition of the Moscow State University led by N. Ryndina (Markevich and Ryndina 1983) and contained a burnt house. Thus, three dwellings and a pit have been excavated.

Beside Tripolye $\mathrm{C} 2$ features, the excavations provided several dispersed fragments and two small bowls of Cucuteni A - Tripolye B1 stage.

Results of investigations remain unpublished; just small reports (Markevich and Ryndina 1983) or conference abstracts (Bicbaev 2014) mention the site and the finds. Selected 
Middle and Late Copper Age settlements from the Brînzeni microzone on the Prut river...317

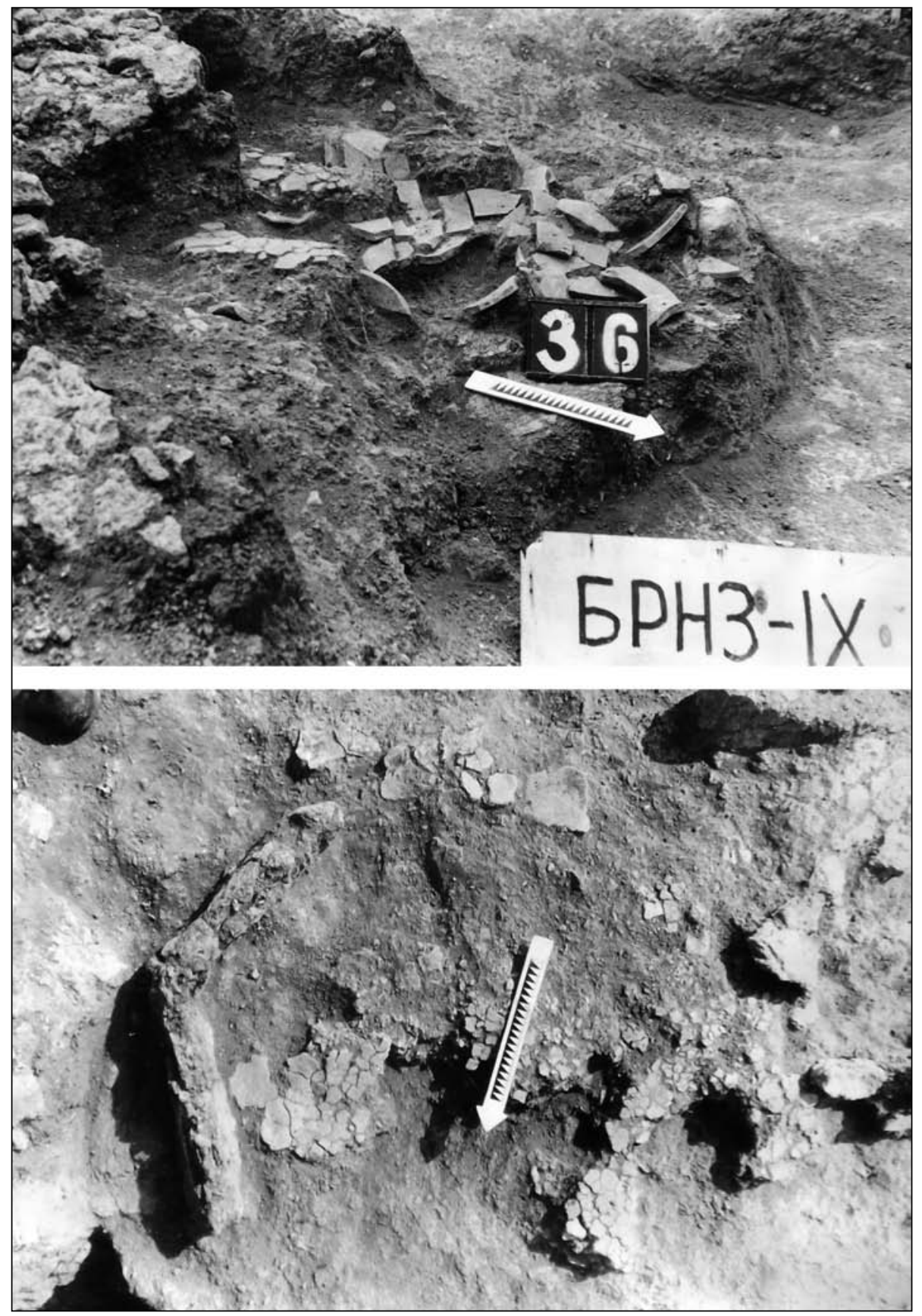

Fig. 24. Brînzeni XI (IX). Up - smashed vessel near a clay installation on the ground floor of the dwelling no. 1. Down - remains of an oven in dwelling no. 2 


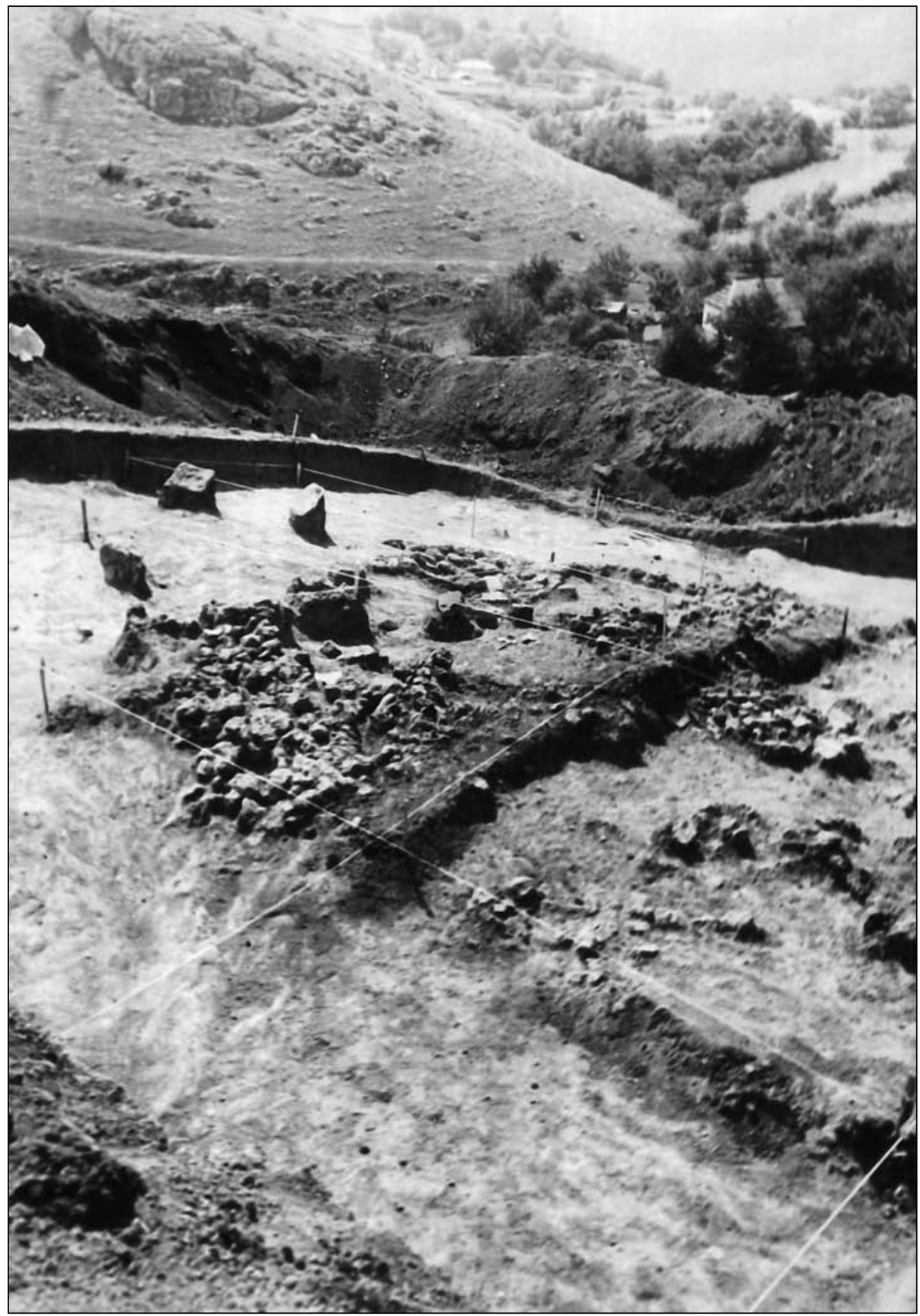

Fig. 25. Brînzeni XI (IX). View over the dwelling no. 2 with the interrelation of the layers corresponding to the two floors 
artefacts have been published in various catalogues (Markevich 1985, 101; Stratulat (chief ed.) 2008, M18). A field report is available only for the trench no. 1 excavated by V. Marchevici and I. Melnichuk, while the documentation of the investigations of Moscow team (trench no. 2) is missing from the Archive of the National Museum of History of Moldova.

\section{Archaeological features}

Dwelling no. 1 had the dimensions of $6.4 \times 5.7 \mathrm{~m}$ and was oriented to the NW-SE axis. The floor of the upper storey consisted of a 5-8 cm thick clay platform mounted on halfbeams of the ceiling. Another thin layer of clay was applied over the platform. Remains from walls with imprints of rods have been encountered on the perimeter. A pentagonal oven was unearthed on the ground floor level. Interesting is the presence of a consistent layer of daub, pottery fragments and bones under the ground floor in the SW part of the dwelling. Here, this layer was about 40-50 cm thick. Under the NE margin of the dwelling, this layer was almost not visible. Most probably, settlement refuse was used for terracing and leveling the slope prior to the construction of the house. The inventory of the dwelling included pottery, spindle whorls, clay weights, bone, antler and stone implements.

Dwelling no. 2 had the dimensions of $9.45 \times 6.25 \mathrm{~m}$ and was also oriented on the NW$\mathrm{SE}$ axis. Its constructional elements are similar to the ones of the first dwelling. Interesting is the fallen segment of a wall near the western margin of the house. It consisted of massive daub pieces with imprints of rods from the wooden frame. Two fireplaces and a clay "table" have been recorded at the ground floor level. The inventory of the dwelling was similar to the one of dwelling no. 1 - pottery, spindle whorls, clay weights and various tools.

A concentration of various tools were recorded to the south of dwelling no. 2. It is possible that a wooden annex was constructed here; it could have subsequently burned out without leaving any archaeological traces.

The pit was situated in the southern part of the trench next to dwelling no. 1. It contained fragments of pottery, animal bones, daub and many bone and antler tools. A complete painted vessel was found on its bottom.

Information on dwelling no. 3 is scarce (Markevich and Ryndina 1983). It is mentioned that the dwelling had the impressive dimensions of $12.5 \times 9 \mathrm{~m}$. Unfortunately, no plan or report is available (on the other hand, in the same publication, the presented dimensions of the dwelling from trench no. 1 are wrong and do not fit the archival documentation). Its construction seems to be similar to the first two ones. The ground floor was covered with a 2-4 cm thick layer of clay with admixture of sand. A clay "table" was found on the upper storey. Another "table" and an oven were recorded at the ground floor level. The inventory is similar to that of the first two houses. 


\section{Pottery and small finds}

The ceramic assemblage belongs to the two main technological categories - fine (75\%) and coarse (25\%) ware. The fine category is made of clay with no visible impurities while the coarse category has crushed shell in the composition of the paste. The outer surface of the vessels is often polished in the ornamented part. Morphologically, bowls (Fig. 26: 9), stumpy small amphorae with handles (Fig. 26: 5), pear-shaped pots (Fig. 26: 1), vessels with spherical body and high truncated (Fig. 26: 3) or low deflected (Fig. 26:4) rim, lids with perforated "ears" are characteristic. The decoration is applied with dark-brown or black paint. Red paint is used more rarely. The ornament is multilayered and consists of festoons, ovals, tangents, vertical, horizontal and undulate lines.

Of special interest are the representations of animals, humans and various signs (Fig. 27: 1-2, 6), particularly remarkable being the painted anthropomorphic figure holding a bow (Fig. 27: 5).

The flint tools are not very numerous and included both local and imported raw materials. Most of them belong to the category of various blades and scrapers. Imported flint was mainly used for blade fabrication. Several flint hammers are also present. Polished stone artefacts include a grinding stone.

The bone and antler industry is both diversified and numerous. In terms of find quantity, antler implements actually represent the second type of artefacts after pottery. Morphologically, most of the antler finds are mattocks and axes as well as semi-finished products. Bone finds are represented mainly by awls. Two bone daggers (Fig. 27: 3) are worthy of mention.

Clay finds include three figurines (Fig. 27: 4) as well as artefacts for textile processing: 22 spindle whorls (Fig. 27: 7-9) and 8 weights (Fig. 27: 10-12). One of the figurines has small stones mounted in the clay paste and marking the eyes.

\section{Settlement's structure and chronological setting}

The internal layout of the settlement is not known. The terracing layers recorded under the ground floor of dwellings indicate that at least some settlement features already existed at the moment of the construction of the investigated houses.

In terms of relative chronology, the site belongs to the Brinzeni local group of the Tripolye $\mathrm{C} 2$ stage.

\section{Perspectives for future research}

The geophysical prospection of the site and radiocarbon dating of the excavated features are necessary for the further evaluation of the settlement and its archaeological potential. Determination of the internal layout of the settlement should provide the 
opportunity to compare it to the structure of the eponymous Brînzeni III site. The relation between the two settlements is also a subject for further investigation.

\section{CONCLUSION}

Taken as a whole, the Brînzeni microzone represents an exemplary case of the succession of settlements from several Cucuteni-Tripolye stages, thus covering almost 1000 years of this culture's development. More than that, certain diachronic peculiarities of the location, layout and material culture of the settlements presented above are in fact characteristic for the respective chronological stages as a whole. The quantification, contextual analysis and comparison of data provided by the Brînzeni sites therefore offer the potential to observe the similarities and differences between settlements representing distinct periods of the Cucuteni - Tripolye evolution.

This is a task for future research. At this point, we shall just outline some of the criteria for further investigation. Thus, there is a clear difference in settlement area between the Tripolye B2 and C1 sites (Brânzeni VIII with 30 ha and Brînzeni IV with 17 ha), on one hand, and the Tripolye C2 sites (Brînzeni III, IX and XI), which do not exceed 2-5 ha. Obvious changes occur also in the settlement layout - from a well-organized centripetal plan in Brînzeni VIII to a rather irregular structure in Brînzeni III. Houses become much smaller. In the pottery complex, the outbreak of signs on Tripolye $\mathrm{C} 2$ fine ware is notorious, with multiple anthropomorphic and zoomorphic investigations. The antler industry also displays deep changes - hundreds of antler implements from Brînzeni III and XI dwellings point towards a much higher level of antler use in regular households in comparison to the preceding Tripolye B2/C1 stages. In regard to anthropomorphic figurines, the sudden decrease of their quantity on Tripolye $\mathrm{C} 2$ stage, observed when comparing settlements from Brînzeni microzone, also represents a general trend for the respective stages of Cucuteni-Tripolye culture, as shown by recent calculations of the quantity of figurines per $100 \mathrm{~m}^{2}$ of investigated area, made on data from over 100 sites (Țerna 2017).

At the same time, one important objective is to complete the older data with modern investigations. Here, a complex approach is necessary, including series of radiocarbon dates made on samples from past excavations, geophysical prospection of settlements as well as application of various methods of natural sciences to the available material. Quantification and statistical analysis of the diachronic categories of finds and features will be also relevant.

To conclude, the Brînzeni area represents one of a few examples of the microzonal approach to Copper Age studies from the Republic of Moldova. Its further investigation in the context of other Prut sites shall be able to provide a clearer picture of movement, consolidation and subsequent change of Cucuteni-Tripolye communities during the formation and disintegration of complex settlements. 


\section{Acknowledgements}

We would like to express our gratitude to V. Bicbaev (National Museum of History of Moldova) for offering us some important information on the older research in Brînzeni. Also, we thank the anonymous reviewers for their valuable comments on the paper.

\section{References}

Ambrojevici C. 1932. L'époque néolithique de la Bessarabie du Nord-Ouest. Contributions à la charte archéologique de la région. Dacia 3-4, 24-45.

Băcăuanu V. 1968. Cîmpia Moldovei. Studiu geomorfologic. Bucureşti: Editura Academiei.

Bicbaev V. M. 2007. «Bashni» Petren (ot arkheologicheskoy interpretatsii aerofotosnimkov k rekonstruktsii zhizni tripolskikh poseleniy). Tyragetia $\mathrm{SN}$ 1, 9-26.

Bicbaev V. M. 2014. Izobrazheniya bogini okhoty s zhivotnymi i luchnikom v rospisi keramiki s pozdnetripolskogo poseleniya Brinzen IX „Valia Bukshiy”. Sesiunea ştiinţifică a Muzeului Naţional de Istorie a Moldovei (ediția a XXIV-a), 16-17 octombrie 2014. Chişinău, 17-19.

Boghian D. 2001. Quelques considerations sur les aspects regionaux du complexe Cucuteni-Tripolye. Memoria Antiquitatis 22, 71-114.

Boghian D., Enea S., Melniciuc A, Setnic E., Ciucălău D., Kovács A., Asăndulesei A. and Stigleț D. 2016. Ripiceni, com. Ripiceni, jud. Botoşani. Punct: Holm / Telescu. Cronica Cercetărilor Arheologice din România 2015, 346-251.

Burtănescu F. and Şadurschi P. 2013. Locuirea eneolitică târzie de la Sadoveni, punctul „Valea Hotarului” (com. Manoleasa, jud. Botoşani). Noi perspective asupra perioadei anterioare Horodiştei în partea de nord a Moldovei. Forum Cultural 13(2), 1-26.

Chapman J., Videiko M., Hale D., Gaydarska B., Burdo N., Rassmann K., Mischka C., Müller J., Korvin-Piotrovskiy A. and Kruts V. 2014. The Second Phase of the Trypillia Mega-Site Methodological Revolution: A New Research Agenda. European Journal of Archaeology 17(3), 369-406.

Chernysh E. K. 1982. Eneolit Pravoberezhnoy Ukrainy i Moldavii. In V. M. Masson and N. Ya. Merpert (eds.), Eneolit SSSR. Moskva: Nauka, 165-320.

Dergachev V. A. 1980. Pamiatniki pozdnego Tripolya. Opyt sistematizatsii. Kishinev: Shtiintsa.

Diachenko A. and Harper T. 2016. The absolute chronology of late Tripolye sites: a regional approach. Sprawozdania Archeologiczne 68, 81-105.

Dinu M. 1977. Complexul cultural Horodiştea-Folteşti. Contribuţia noilor cercetări arheologice la problema perioadei de tranziție de la eneolitic la epoca bronzului din zona est-carpatică a României. Iaşi (unpublished $\mathrm{PhD}$ thesis).

Dumitrescu H. 1945. La station préhistorique de Horodiştea, sur le Pruth. Dacia 9-10, 127-163.

Dumitroaia Gh. 2000. Comunităţi preistorice din nord-estul României. De la cultura Cucuteni pînă în bronzul mijlociu (= Bibliotheca Memoriae Antiquitatis 7). Piatra-Neamț: Editura „Constantin Mătasă”.

Hofmann R., Țerna S., Rud V., Shatilo L. and Sîrbu Gh. 2016. Geomagnetic surveys and archaeological test-trenches on early Neolithic - late Copper Age sites from Republic of Moldova. In 
D. Mischka, C. Mischka and C. Preoteasa (eds.), Beyond excavation. Geophysics, aerial photography and the use of drones in Eastern and South-East European archaeology. International colloquium programme and abstracts. Piatra-Neamț: Editura „Constantin Mătasă”, 18-22.

Levițki O., Sîrbu Gh., Sîrbu L. and Heghea S. 2013. Cercetările arheologice din situl Trinca - La Şanț, campania anului 2011. Rezultate preliminare. Revista Arheologică SN 9(2), 136-160.

Levițki O., Sîrbu Gh. and Bajureanu I. 2016. Microzona Trinca în contextul eneoliticului est-carpatic. In S. Țerna and B. Govedarica (eds.), Interactions, changes and meanings. Essays in honour of Igor Manzura on the occasion of his $60^{\text {th }}$ birthday. Chişinău: Stratum Plus, 255-271.

Manzura I. 1994. Manifestări culturale în perioada de tranziție. Thraco-Dacica 15(1-2), 103-119.

Manzura I. 2003. Copper axes and bracelets in the cultural context of Prehistoric Europe. In L. Nikolova (ed.), Early Symbolic Systems for Communication in Southeast Europe 2 (= British Archaeological Reports. International Series 1139). Oxford: Archaeopress, 371-418.

Mareş I. 2012. Metalurgia aramei în civilizaţiile Precucuteni şi Cucuteni. Suceava: Editura Universității „Ştefan cel Mare”, editura „Karl A. Romstorfer”.

Markevich V. I. 1973. Pamiatniki epokh neolita i eneolita (= Arkheologicheskaya karta Moldavskoy SSR 2). Kishinev: Shtiintsa.

Markevich V. I. 1980. Otchiot o polevykh issledovanyakh Moldavskoy arkheologo-etnograficheskoy ekspeditsii $v 1979 \mathrm{~g}$. Kishinev (unpublished typescript stored in Archive of the National Museum of History of Moldova, report no. 149).

Markevich V. I. 1981. Pozdnetripolskiye plemena Severnoy Moldavii. Kishinev: Shtiintsa.

Markevich V. I. 1981a. Otchiot o polevykh issledovanyakh 1980 goda, provedionnykh Moldavskoy arkheologo-etnograficheskoy sektora narodnoy kultury s MAE. Kishinev (unpublished typescript stored in Archive of the National Museum of History of Moldova, report no. 158).

Markevich V. I. 1982. Raskopki na poselenii Brinzeny IV (yama etapa B1). Kishinev (unpublished typescript stored in Archive of the National Museum of History of Moldova, report no 188), 104-116.

Markevich V. I. 1985. Mărturii ale trecutului. Delekoye-blizkoye. These remote near ages. Kishinev: Izdatelstvo "Timpul".

Markevich V. I. 1987. Gorodishche Brinzeny III. In N. A Demchenko (ed.), Svod pamiatnikov istorii i kultury Moldavskoy SSR. Severna zona. Maket. Kishinev: Shtiintsa, 289-291.

Markevich V. I. 1990. O kultovykh sooruzheniyakh tripolskoy kultury v Dnestrovsko-Prutskom mezhdureche. In M. T. Kashuba (ed.), Drevneyshiye obshchnosti zemledeltsev I skotovodov Severnego Prichernomoria (V tys. Do n.e. - V v. n.e.). Materialy mezhdunarodnoy konferentsii. Kishinev, 10-14 dekabrya 1990. Kiev, 50-51.

Markevich V. I. and Ryndina N. V. 1983. Raskopki pozdnetripolskogo poselenya Brynzen IX. Arkheologicheskiye otkrytya $v 1981 \mathrm{~g}$. Moskva, 398-399.

Melnichuk I. V. 1982. Raskopki na poselenii Brynzeny IX Edinetskogo rayona. Kishinev (unpublished typescript stored in Archive of the National Museum of History of Moldova, report no 188), 213-262. 
Melniciuc A. and Boghian D. 2010. Locul staţiunii Ripiceni - punctul la Holm (Telescu) în contextul fazei Cucuteni A-B. Forum Cultural 10(4), 6-9.

Moroşan N. 1929. Noi contribuții preistorice asupra Basarabiei de Nord. Memoriile sesiunii ştiințifice a Academiei Române - seria 3, year 1, vol. 6, 34-45.

Müller J., Rassmann K. and Videiko M. Y. (eds.) 2016. Trypillia-Megasites and European Prehistory 410o-340o BCE. Leeds: Routledge.

Niţu A. and Şadurschi P. 1994. Săpăturile de salvare de la „Stânca Doamnei” (sat Stânca - Ştefăneşti, județul Botoşani). Hierasus 9, 181-194.

Rassmann K., Ohlrau R., Hofmann R., Mischka C., Burdo N., Videjko M. Ju. and Müller J. 2014. High precision Tripolye settlement plans, demographic estimations and settlement organization. Journal of Neolithic Archaeology 16, 63-95.

Rassmann K., Mertl P., Voss H.-U., Bicbaiev V. and Musteață S. 2016. Copper age settlements in Moldova: insights into a complex phenomenon from recent geomagnetic surveys. In J. Müller, K. Rassmann and M. Videiko (eds.), Trypillia-Megasites and European Prehistory. 410o340o BCE. Leeds: Routledge, 55-70.

Reimer P., Bard E., Bayliss A., Warren Beck J., Blackwell P., Bronk Ramsey C., Buck C., Cheng H., Lawrence Edwards R., Friedrich M., Grootes P., Guilderson T., Haflidason H., Hajdas I., Hatté C., Heaton T., Hoffmann D., Hogg A., Hughen K., Felix Kaiser K., Kromer B., Manning S., Niu M., Reimer R., Richards D., Marian Scott E., Southon J., Staff R., Turney C. and van der Plicht J. 2013. IntCal 13 and Marine 13 radiocarbon age calibration curves 0-50,000 years cal BP. Radiocarbon 55(4), 1869-1887.

Sorochin V. 1993. Modalitățile de organizare a aşezărilor complexului cultural Cucuteni-Tripolie. Arheologia Moldovei 16, 69-86.

Sorochin V. 2001. Plastica antropomorfă din aşezarea cucuteniană Brânzeni VIII, jud. Edineț. Memoria Antiquitatis 22, 137-156.

Sorochin V. 2004. Aşezările cucuteniene de tip Solonceni. Memoria Antiquitatis 23, 167-202.

Sorokin V. Ya. 1990. K probleme khronologii pamyatnikov srednego Tripolya Moldavii. In Zbenovich V. G. (ed.), Rannezemledelcheskiye poselenya-giganty tripolskoy kultury na Ukrainie. Talianki, 94-101.

Stratulat L. (ed.) 2008. Cucuteni-Trypillia: a great civilisation of Old Europe. Palazzo della cancelleria, Rome - Vatican, 16 September - 31 October 20o8. Vatican: Palazzo della cancelleria.

Stratulat L. (ed.) 2009. Cucuteni - magia ceramicii. Iaşi: Complexul muzeal național „Moldova”.

Ţerna S. 2016. Geomagnetic surveys of the Neolithic and the Copper Age sites from the Republic of Moldova (1968-2016): main results, current state and future perspectives. Raport 11, 189-225.

Ţerna S. 2017. K voprosu o rasprotranenii melkoy antropomorfnoy plastiki na poselenyakh kultury Cucuteni-Tripolye. Kratkiye Soobshchenya Instituta Arkheologii 2, in print.

Țerna S., Rassmann K., Vasilache M. and Radloff K. 2016. Stolniceni I - new research on a CucuteniTripolye large site. In A. Zanoci, E. Kaiser, M. Kashuba, E. Izbitser and M. Băț (eds.). Mensch, Kultur und Gesellschaft von der Kupferzeit bis zur frühen Eisenzeit im nördlichen Eurasien. Beiträge zu Ehren zum 6o. Geburtstag von Eugen Sava. Chişinău, 137-148. 
Ţerna S., Rassmann K. and Radloff K. 2016. The Cucuteni-Tripolye settlement of Stolniceni I (Moldova): geophysical and archaeological investigations (2015-2016). In D. Mischka, C. Mischka and C. Preoteasa (eds.), Beyond excavation. Geophysics, aerial photography and the use of drones in Eastern and South-East European archaeology. International colloquium programme and abstracts. Piatra-Neamț: Editura „Constantin Mătasă”, 65-69.

Țerna S., Rassmann K. and Rud V. 2017. Goncharniy gorn s pozdnetripolskogo poselenya Stolnichen I (Edinetskiy rayon, Respublika Moldova) i proizvodstvo keramiki k vostoku ot Karpat v 4-m tysiachletii do n.e. Stratum Plus 2, 301-330.

Titov V. S. and Markevich V. I. 1974. Noviye danniye o zapadnykh sviazakh pozdnego Tripoya. Sovetskaya arkheologiya 3, 150-164.

Uhl R., Vasilache-Curoşu M., Bicbaev V., Sîrbu M. and Sîrbu L. 2016. Bericht über die archäologischen Arbeiten in Petreni, Republik Moldau. Tyragetia SN 10(1), 165-174.

Videiko M. 200o. Tripolye and the cultures of Central Europe. Facts and the character of interactions: 4200-2750 BC. Baltic-Pontic studies 9, 13-68.

Vornicu-Țerna A. and Țerna S. 2016. Ripiceni - Popoaia: a new Cucuteni B settlement from NorthEastern Romania. Memoria Antiquitatis in print

Wechler K.-P. 1994. Zur Chronologie der Tripolje-Cucuteni-Kultur aufgrund von 14C-Datierungen. Zeitschrift für Archäologie 28(1), 7-21.

Weninger B. and Harper T. 2015. The geographic corridor for rapid climate change in Southeast Europe and Ukraine. In S. Hansen, P. Raczky, A. Anders and A. Reingruber (eds.), Neolithic and Copper Age between the Carpathians and the Aegean Sea. Chronologies and Technologies from the $6^{\text {th }}$ to the $4^{\text {th }}$ Millennium BC (= Archäologie in Eurasien 31). Bonn: Habelt, 474-494. 
